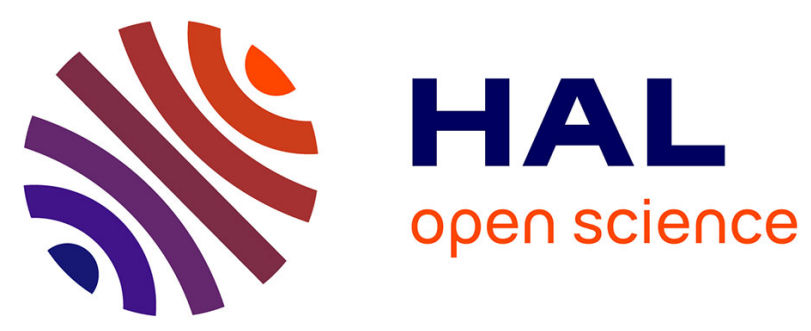

\title{
Evidence for Paleocene-Eocene evolution of the foot of the Eurasian margin (Kermanshah ophiolite, SW Iran) from back-arc to arc: Implications for regional geodynamics and obduction
}

Hubert Whitechurch, Jafar Omrani, Philippe Agard, F. Humbert, R. Montigny, Laurent Jolivet

\section{To cite this version:}

Hubert Whitechurch, Jafar Omrani, Philippe Agard, F. Humbert, R. Montigny, et al.. Evidence for Paleocene-Eocene evolution of the foot of the Eurasian margin (Kermanshah ophiolite, SW Iran) from back-arc to arc: Implications for regional geodynamics and obduction. Lithos, 2013, 182-183, pp.11-32. 10.1016/j.lithos.2013.07.017 . insu-00858309

HAL Id: insu-00858309

https://hal-insu.archives-ouvertes.fr/insu-00858309

Submitted on 17 Sep 2014

HAL is a multi-disciplinary open access archive for the deposit and dissemination of scientific research documents, whether they are published or not. The documents may come from teaching and research institutions in France or abroad, or from public or private research centers.
L'archive ouverte pluridisciplinaire HAL, est destinée au dépôt et à la diffusion de documents scientifiques de niveau recherche, publiés ou non, émanant des établissements d'enseignement et de recherche français ou étrangers, des laboratoires publics ou privés. 


\section{Evidence for Paleocene-Eocene evolution of the foot of the Eurasian margin (Kermanshah ophiolite, SW Iran) from back-arc to arc: Implications for regional geodynamics and obduction}

- H. Whitechurch ${ }^{\mathrm{a}}$

- J. Omranibc

- P. Agard ${ }^{\mathrm{cd}}$

- F. Humbert ${ }^{\mathrm{a}}$

- R. Montigny ${ }^{\mathrm{a}}$

- L. Jolivet ${ }^{\mathrm{de}}$

- ${ }^{a}$ IPGS, Université de Strasbourg, CNRS UMR 7516, 1, rue Blessig, 67000 Strasbourg, France

- $\quad{ }^{\mathrm{b}}$ Geological Survey of Iran, Mehraj Bd., Tehran, Iran

- $\quad{ }^{\mathrm{c}}$ UPMC Univ Paris 06, ISTEP, CNRS UMR 7193, F-75005 Paris, France

- ${ }^{\mathrm{d}}$ IUF, 103 bd St Michel, Paris, France

- $\quad$ e Institut des Sciences de la Terre d'Orléans, UMR 6113, Université d'Orléans, 1A rue de la Férollerie, 45071 Orléans, France

\section{Highlights}

Kermanshah ophiolites consist of the Paleocene back-arc basin and the lower Eocene arc. These ophiolites extend to the NW (Khoy, NW Iran and Eastern Taurus, Turkey).

Slowing Arabia-Eurasia convergence induces the slab retreat with back-arc extension. The lower Eocene arc intrudes the Paleocene back-arc basin close to the Eurasian margin. Obduction of Early Tertiary back-arc, arc assemblage occurred during Oligocene.

\footnotetext{
Abstract

The nature and significance of the Kermanshah ophiolite (Zagros Mountains, Iran), traditionally identified as one of the remnants of the Peri-Arabic ophiolite system obducted onto Arabia in the Late Cretaceous, is reinvestigated in this study. We assess the geochemistry of magmatic rocks from two distinct areas: the Kamyaran Paleocene-Eocene arc and the so-called Harsin-Sahneh ophiolite complex. Volcanic rocks associated with Triassic to Liassic sediments display a clear alkali signature, whereas the Paleocene volcanic rocks show a geochemical signature similar to that of tholeiitic back-arc basin basalts. The presumed ophiolitic gabbros of the Harsin-Sahneh complex and some of the associated dykes that intrude harzburgites or gabbros also have a back-arc basin signature. Eocene volcanics, gabbros and dykes intruding the harzburgites display clear low to medium-K calc-alkaline signatures with variable negative $\mathrm{Nb}$, Ta, and $\mathrm{Ti}$ and positive $\mathrm{Sr}, \mathrm{Ba}, \mathrm{Th}$, and $\mathrm{U}$ anomalies. Field relationships and geochemical evidence indicate that the Eocene magmatic rocks were intruded into a mantle substratum close to the ocean-continent transition. The geochemistry of magmatic rocks from Paleocene to Eocene suggests that an Eocene arc was constructed in a Paleocene back-arc basin along the Eurasian continental margin. In the Kermanshah region this magmatic activity, which extended further to the northwest into Turkey, coincided with a marked slowing down of the convergence of Arabia with Eurasia. Furthermore, it occurred after the Mesozoic Sanandaj-Sirjan magmatism had ceased but before the development of the
} 
Tertiary Urumieh-Dokhtar magmatic arc. We tentatively relate this transient magmatic activity to a slab retreat and a back-arc extension at the Eurasian continental margin.

\section{Keywords}

- Tethyan ophiolites;

- Back-arc and arc magmatism;

- Active Eurasian margin;

- Iran;

- Zagros;

- Kermanshah

\section{Introduction}

The geodynamic evolution of the Tethyan realm is dominated by the existence of long-lived, active subduction zones to the north, beneath Eurasia, resulting in the detachment and northward migration of continental fragments from the Gondwana (Agard et al., 2011, Dercourt et al., 1986, Guillot et al., 2003, Ricou, 1994, Sengor et al., 1988 and Stampfli and Borel, 2002). An example of one of these continental fragments is the Central Iranian block, which collided with Eurasia in the Lower to Middle Triassic (Saidi et al., 1997, Sengor, 1990 and Stampfli and Borel, 2002). Oceanic subduction beneath the active margin of Central Iran continued from the Upper Triassic to the Oligocene until the Tertiary collision of Arabia with Eurasia. Evidence of this active subduction is preserved as magmatic arcs within the overriding plate, i.e., the Sanandaj-Sirjan arc formed in the Mesozoic and the UrumiehDokhtar arc in the Tertiary ( Omrani et al., 2008). These remnant arcs are found along a suture zone running along the present-day Main Zagros Thrust (MZT; e.g., Agard et al., 2005 and references therein).

This protracted convergence was, however, affected by a significant obduction event across the whole Neotethys, from Turkey to the Himalayas (Coleman, 1971 and Ricou, 1971), which was coeval with major geodynamic changes (Agard et al., 2006 and Monié and Agard, 2009). Extensive ophiolitic thrust nappes were obducted onto the Arabian platform from Oman to Turkey (Fig. 1) in the Campanian-Maastrichtian, following the inception of oceanic detachment at 100-95 Ma (Agard et al., 2007, Coleman, 1981, Hacker, 1994, Thuizat et al., 1981 and Whitechurch et al., 1984). Irrespective of the internal structure of the ophiolites, the organisation of the ophiolite-bearing nappe pile, thrust onto the Gondwanian margin is almost identical to that of the Arabian plate (Ricou, 1971). Within the nappes the bottom of the pile consists of radiolarian-bearing and continental slope sediments from a basin at the foot of the deepest part of the continental margin. These radiolarian-bearing nappes are often overlain by exotic blocks composed mainly of volcanic rocks and sedimentary reef formations of Triassic age, representing offshore seamounts from the most distal part of the southern margin of the Tethys. Ophiolitic nappes, often underlain by metamorphic soles, overlie this structural pile. These ophiolites were all thrust onto the Arabian platform over a detrital flysch basin containing blocks sheared off the advancing nappes. 


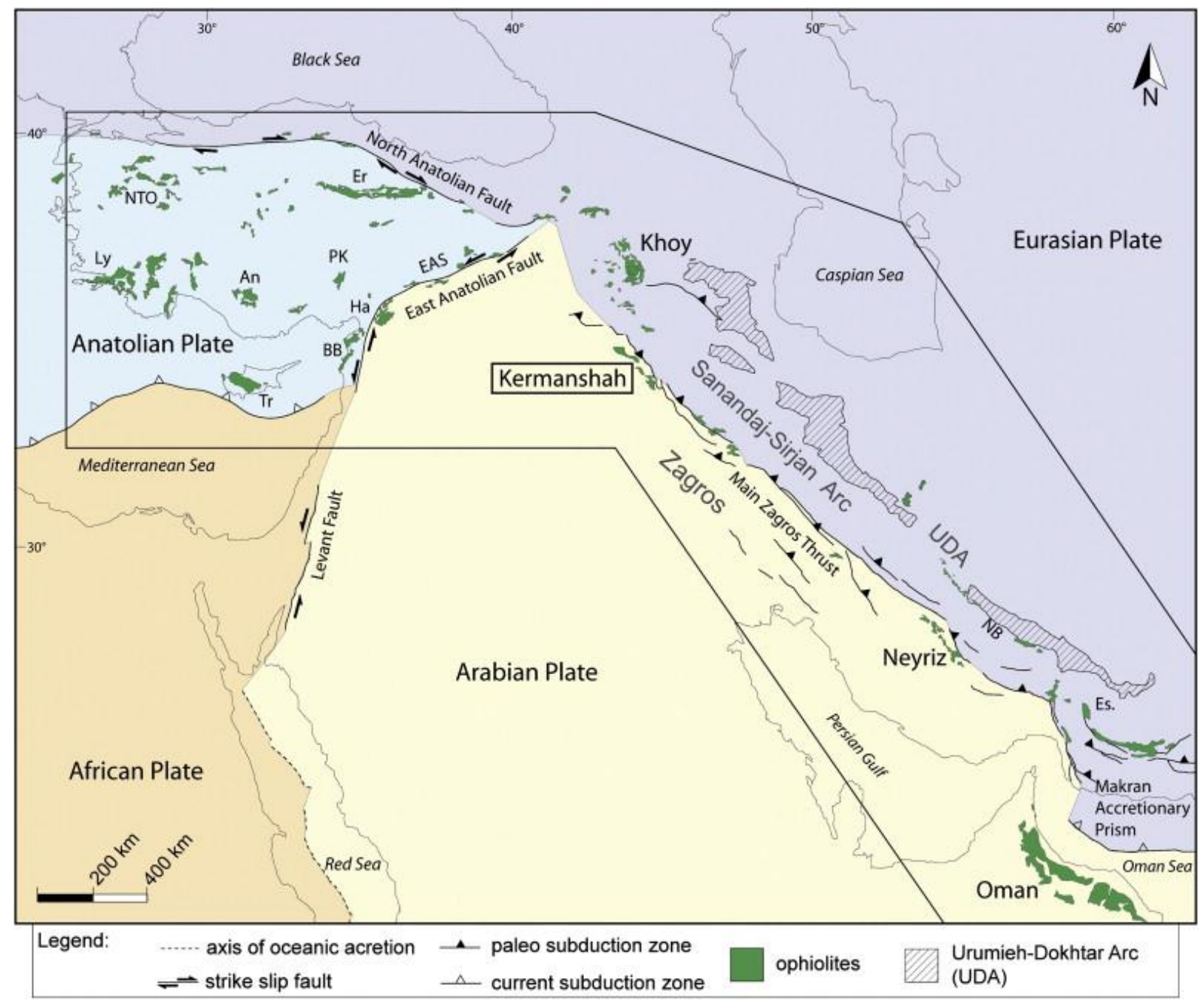

Fig. 1.

Simplified tectonic map showing the Eurasian, African and Arabian Plates, the major continental sutures and subduction zones (represented, respectively, with black and white triangles), and allochtonous regions containing ophiolites (green). NTO: Northern Tauric ophiolites; Ly: Lycian ophiolite; An: Antalya ophiolite; Tr: Troodos ophiolite; Me: Mersin ophiolite; PK: Pozanti-Karsanti ophiolite; Er: Erzincan ophiolite; ETO: Eastern Tauric ophiolites; Ha: Hatay ophiolite; BB: Baër-Bassit ophiolite; NB: Nain-Baft ophiolite; Es: Esfandegheh ophiolite.

In contrast to the Oman ophiolite, however, both the Neyriz and Kermanshah ophiolites, located in Iran along the MZT (Fig. 1) are affected by collision and differ markedly from the classic ophiolite sequence recognised in Oman. In the Kermanshah (NW Zagros) ophiolite, Braud (1970, 1987) identified two distinct components, an obduction-related part and a Tertiary arc (Harsin and Kamyaran, respectively). Ghazi and Hassanipak (1999) later suggested that these are both components of the Kermanshah ophiolite. The Neyriz ophiolite (SE zagros), which is intimately associated with huge pieces of marble and contains only a limited amount of oceanic crust (Hall, 1981, Jannessary, 2003 and Ricou, 1976), was interpreted to have formed in an ocean-continent transition zone of the Gondwanian margin (Jannessary, 2003). 
This paper focuses on the petrology and geochemistry of the Kermanshah ophiolite as one important key element of the Peri-Arabic ophiolite system between Oman and Turkey. Interpretation of the different magmatic systems emplaced through time in this composite socalled ophiolite, is tentatively interpreted in terms of kinematic changes during Tethyan convergence.

\section{Geological setting}

\subsection{Zagros convergence and ophiolite remnants in the crush zone}

The geodynamic context of the Zagros orogeny has been investigated by a number of workers (Agard et al., 2005 and Agard et al., 2011 and references therein; Hatzfeld et al., 2003, Hessami et al., 2001 and Lacombe et al., 2007), and only its main features are summarised here. The Zagros orogen, which separates the northern active margin of Eurasia and the southern passive margin of Arabia, is the result of a protracted history of convergence with three main phases:

a)

Oceanic subduction of Tethys beneath the active Eurasiatic margin and subsequent arc magmatism (200-35 Ma).

Two magmatic belts of predominantly calc-alkaline volcanic and plutonic rocks (Berberian and Berberian, 1981), the Sanandaj-Sirjan and Urumieh-Dokhtar arcs, define NW-SE linear arrays along the Zagros Mountains within the overriding Eurasian plate. The magmatic activity was restricted to the Mesozoic for the Sanandaj-Sirjan arc and to the Tertiary for the Urumieh-Dokhtar arc (Fig. 1 and Fig. 2a). The Sanandaj-Sirjan arc is thought either to be part of Central Iran (Stöcklin, 1968) or to represent an elongate microcontinent (Alavi, 1994). However no ophiolite occurs between them, except in the southern part, along the short-lived, late Cretaceous to Paleocene Nain-Baft back-arc domain (Arvin and Robinson, 1994 and Shafaii Moghadam et al., 2009). 

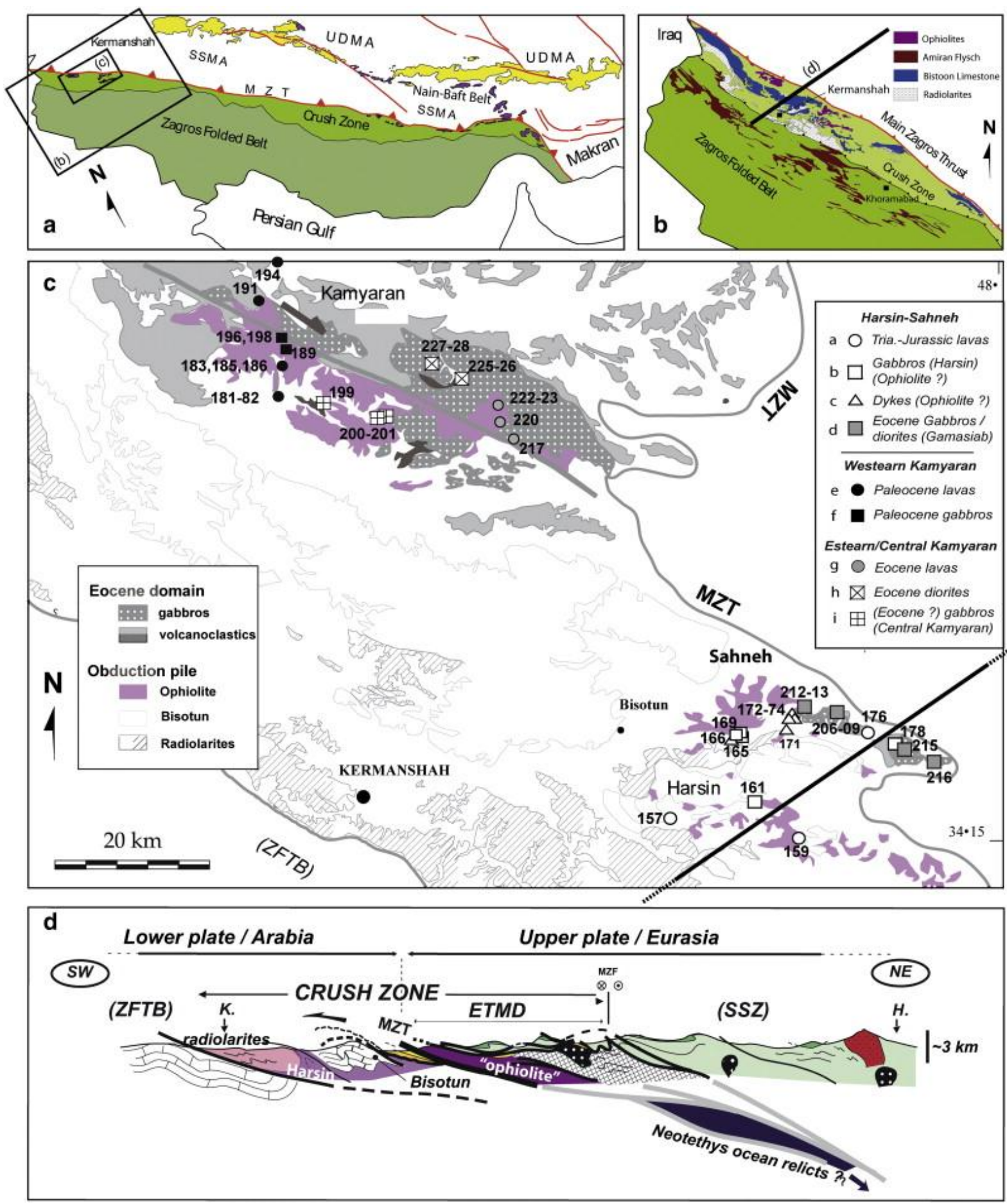

Fig. 2.

(a) Tectonic map showing the positions of the Zagros Folded Belt, the Crush Zone, the Main Zagros Thrust (MZT), the Mesozoïc Sanandaj-Sirjan Arc (SSA), the Nain-Baft Cretaceous Marginal Basin, the Eocene to Quaternary Umurieh-Doghtar Arc (UDA), the Cretaceous to present Makran accretionary prism and the study area in Kermanshah (rectangles) main units discussed in this paper. (b) Simplified geological map (based on 1/250,000 maps Geological Survey of Iran) showing the main tectonic units of the Kermanshah region. (c) Simplified geological map of the Kermanshah area (based on1/100,000 maps; Geological Survey of Iran) showing the main geological units of the Kamyaran and Harsin regions, the trace of the crosssection of Fig. $2 d$ in the Harsin region (dark line) and the location, numbers, and nature of the 
samples analysed in the paper. (d) Composite cross-section south of Kangavar and east of Harsin (precise location in Fig. 2c; modified after Agard et al., $200 Z$ and Agard et al., 2011). Black and dotted: gabbros (ca. 40-38 Ma), which intrude the Eocene domain (see Fig. 3).

b) A distinctive period of disturbance of the subduction processes $(\sim 100-80 \mathrm{Ma})$.

Following the marked increase in convergence velocities across the Neotethys at $115 \mathrm{Ma}$ (Agard et al., 2007), two regional-scale (> $3000 \mathrm{~km}$ along strike), short-lived and coeval major tectonic phenomena occurred: (1) the development of intra-oceanic subduction, ultimately leading to the obduction of oceanic lithosphere onto Arabia (e.g., Nicolas, 1989 and Searle and Cox, 1999), and (2) the transient exhumation of oceanic blue schists along the Neotethyan subduction zone (Monié and Agard, 2009). Another major, but poorly understood, geodynamic change occurred at the end of the Mesozoic, when the magmatic activity shifted northward by some $\sim 300 \mathrm{~km}$, from the Sanandaj-Sirjan arc to the Urumieh-Dokhtar arc ( Fig. 2a) (Berberian and Berberian, 1981 and Omrani et al., 2008). During this period, several short-lived back-arc basins opened along the southern margin of the Iranian Block and these ultimately accreted to the Eurasian continent, e.g., the Nain-Baft seaway, which closed during the early Paleocene ( Agard et al., 2011, Arvin and Robinson, 1994 and Shafaii Moghadam et al., 2009).

c) The timing of the collision

The timing of the end of subduction and inception of the collision, between Arabia and Eurasia has long been debated in the literature, with dates ranging from the Upper Cretaceous (Alavi, 1994) to the Plio-Quaternary (Tchalenko and Braud, 1974). Agard et al. (2005) suggested that collision started prior to 25-23 Ma in Northern Zagros Mountains and resulted in $70 \mathrm{~km}$ of shortening over the last 20-15 Ma alone within the Zagros Mountains south of the MZT and northwest of the Thrusted Zagros. Most authors now regard the collision as having begun during the Late Eocene-Early Oligocene (Agard et al., 2005, Ballato et al., 2011, Van Huen and Allen, 2011 and Vincent et al., 2005). The collision intensified during the Upper Miocene, as revealed by the increased shortening in the High Zagros Mountains and the so-called "crush zone" (see Fig. 2a, b, c), a narrow thrust zone sandwiched between Arabia and Eurasia, bounded to the northeast by the MZT, and to the southeast by the Zagros Fold Belt (Berberian, 1995 and Falcon, 1974). Another indication of such intensification is the propagation of deformation in the Zagros foreland (Homke et al., 2004, Homke et al., 2009, Molinaro et al., 2005, Mouthereau et al., 2007 and Verges et al., 2011). Collision was likely accompanied by slab tear at depth during the Mio-Pliocene (105 Ma to present), as evidenced by the resumption of magmatism of adakitic affinity in the Urumieh-Dokhtar arc (Jahangiri, 2007 and Omrani et al., 2008).

The Kermanshah ophiolite is located in the crush zone (Fig. 2a, b, c). The thrust sheets of the crush zone comprise of, from bottom to top: radiolarites $(\sim 500 \mathrm{~m})$, exotic limestones (Bisotun; $3000 \mathrm{~m}$ ), dismembered ophiolite, and Eocene magmatic rocks, all overlain by thrust sheets of Paleozoic-Mesozoic rocks of the Sanandaj-Sirjan Zone (Agard et al., 2005 and Braud, 1987; Fig. 2d).

Within the crush zone, which runs discontinuously along the entire length of the Zagros Mountains, only two regions, i.e., Kermanshah and Neyriz, contain extensive ophiolitic units. 
In Neyriz, the ophiolite together with the Pichakun radiolarites and the exotic volcanic edifices overlain by reef formations, rest on the Coniacian sediments of the Arabian continental margin platform. Late Maastrichtian Tarbur Formation unconformably overlies these nappes ( Ricou, 1971 and Ricou et al., 1977). In the Kermanshah region, radiolarite blocks up to several $100 \mathrm{~m}$ in diameter lie on the top of the Campanian Gurpi formation and in the Maastrichtian Amiran flysch ( Braud, 1987). Radiolarite thrust sheets were therefore emplaced somewhat diachronously onto the Arabian platform in Santonian to Maastrichtian times.

\subsection{Previous work on the Kermanshah "ophiolite"}

Braud (1987) suggested that the Kermanshah region was made up of two distinct zones. The first one is the ophiolite proper, the Harsin-Sahneh complex to the southeast (Fig. 2c), which primarily consists of peridotite, intruded by gabbros, isolated dykes, dyke swarms but never sheeted dykes as observed in Oman, and covered by basaltic flows showing rare pillow structures. Braud (1987) proposed that the ophiolite was obducted in the Cretaceous. The second zone consists of a magmatic domain, which is largely exposed in a vast area that stretches along the road to Nourabad, from the East of Sahneh to the North of Kamyaran (Fig. 2c). The domain corresponds to several thrust sheets composed of sheared serpentinites, lava flows, and intercalated sediments of Paleocene to Middle Eocene age (Braud, 1987 and Shahidi and Nazari, 1997). Large gabbroic and dioritic intrusions crosscut the Paleocene-Eocene lava flows and sediments. Marls and siliceous limestones interlayered within the mafic lavas of the same region yielded Paleocene-Eocene paleontological ages (Braud, 1987).

Despite being a major outcrop along the so-called Peri-Arabic ophiolite crescent (Ricou, 1971), the geochemical nature of the Kermanshah ophiolite still remains unclear. The Kermanshah ophiolite was first considered to be a mid-ocean ridge remnant analogous to those of Oman and Neyriz (Ricou, 1971 and Ricou et al., 1977). Later, Desmons and Beccaluva (1983) proposed an island arc origin for the volcanic rocks of the entire Kermanshah complex. Leterrier (1985) also reported isotopic and geochemical characteristics that support the suggestion that an oceanic island arc cut through the northwestern part of the ophiolite (near Kamyaran; Fig. 2c). On the basis of a tectonic analysis, Braud and Bellon (1974) and Braud (1987) interpreted the ophiolites and crosscutting arc as separate remnants of a slow-spreading Eocene oceanic domain that existed just before the collision between Arabia and Eurasia. Ghazi and Hassanipak (1999) recognised two different magmatic groups: 1) a sub-alkaline suite with light rare earth element (LREE) enrichment and incompatible trace element patterns suggesting an island arc affinity, and 2) a volcanic group with a significant LREE enrichment similar to typical intra-plate oceanic island basalt (OIB). However, they considered the Kermanshah ophiolite to be a single unit from Nourabad to Kamyaran in contrast with the findings of Braud (1987).

More recently, Allahyari et al. (2010) studied the peridotites and intrusive ultramafic and gabbroic rocks mainly between Harsin and Sahneh and along the Gamasiab River. They characterised the Harsin-Sahneh domain as a melange with ophiolitic fragments. No clear distinction of nappe tectonic organisation (Braud, 1987), stratigraphic age, or isotopic age could be made among the various units. The authors concluded from their petrological and geochemical analyses that the gabbros are either enriched mid-ocean ridge basalts (EMORBs), generated during the early stage of oceanic spreading, or normal mid-ocean ridge basalts (N-MORBs), generated in a mid-oceanic environment. They nevertheless interpreted 
the ultramafic rocks, i.e., lherzolites to harzburgites, as residual mantle enriched in LREE by subduction-derived fluids after the extraction of boninitic melts in an intra-oceanic arc setting.

The published stratigraphic ages allow dating of some units in both the Harsin-Sahneh and the Kamyaran regions. Around Harsin, the limestones directly overlying serpentinites were dated as Upper Triassic because of the presence of Megalodon (Braud, 1987). In other places, the limestones resting on radiolarites overlying the same serpentinites were dated as Malm. The serpentinised peridotites are considered to be mantle material exhumed during the Early Mesozoic break-up of the Neo-Tethyan Ocean (Wrobel-Daveau et al., 2010). Locally, Maastrichtian sediments rest unconformably on the peridotites (Karimi Bavandpour, 1999 and Shahidi and Nazari, 1997). The radiolarites have recently been shown to span the range from Liasic to Turonian (Gharib and de Wever, 2010), with some being interpreted as Liassic extensional allochtons by Wrobel-Daveau et al. (2010).

Only a few radiometric age constraints are available for the ophiolite in the Harsin-Sahneh area. K-Ar dating of the so-called Harsin-Sahneh dyke complex (Delaloye and Desmons, 1980) yielded a whole-rock age of $86.3 \pm 7.8 \mathrm{Ma}$, (i.e., Campanian) for a leucodiorite surrounding dolerite dykes. A more reliable $\mathrm{K}-\mathrm{Ar}$ date, obtained on an amphibole fraction isolated from a dyke, yielded a Campanian age of $81.4 \pm 3.8 \mathrm{Ma}$, which indicates that some of the dykes are Cretaceous in age. In comparison, the available $\mathrm{K}$-Ar ages for the Neyriz ophiolite range from $77 \pm 2.4 \mathrm{Ma}$ to $104 \pm 1.0 \mathrm{Ma}$ ( Lanphere and Pamic, 1983). An ${ }^{40} \mathrm{Ar}-$ ${ }^{39}$ Ar plateau age of $93 \pm 1.5 \mathrm{Ma}$, on amphibole from a foliated gabbro of the Neyriz ophiolitic complex ( Jannessary, 2003) is similar in age to a zircon ${ }^{238} \mathrm{U}-{ }^{206} \mathrm{~Pb}$ age from the Oman ophiolite, i.e., 95-90 Ma ( Tilton et al., 1981).

As part of our study in the Kermanshah region, we measured a conventional $\mathrm{K}-\mathrm{Ar}$ age of $56 \pm 9 \mathrm{Ma}$ (i.e., the Paleocene-Eocene boundary), on amphibole from a diorite crosscutting Paleocene volcanic and sedimentary rocks (Lower Eocene flysch along the Gamasiab River in the Sahneh region, sample 209, Fig. 3). In the Kamyaran region, some of the volcanic rocks are interbedded with Paleocene-Lower Eocene sediments. These volcanic units are tectonically associated with serpentinised peridotite slices crosscut by dykes. Finally, these volcanic units are intruded by late isotropic gabbroic to dioritic plutons dated by Leterrier (1985) as of $34 \pm 1 \mathrm{Ma}$, i.e., Oligocene (Rb-Sr age). A new $\mathrm{K}-\mathrm{Ar}$ age determination (this study), on a biotite from such a late dioritic intrusion north of the Kamyaran region, yielded an Oligocene age of $26.5 \pm 2.4 \mathrm{Ma}$.

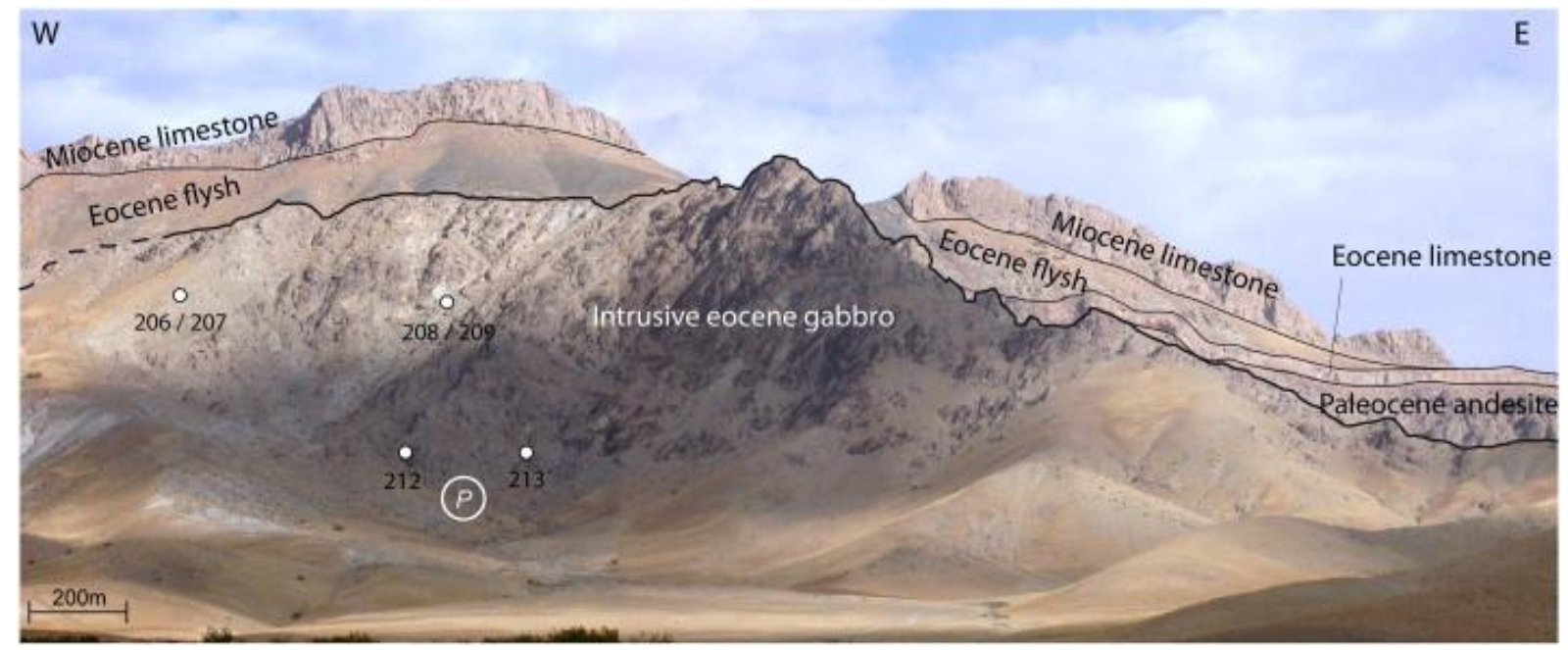




\section{Fig. 3.}

Eocene gabbroic intrusion in Paleocene volcanics and Eocene flysch covered by the Miocene limestones of the Qom formation (Gamasiab Valley, SE of Sahneh); P: zone with slices of harzburgites.

In summary, two domains coexist in the Kermanshah ophiolitic region: a Cretaceous ophiolitic domain and a Tertiary calc-alkaline arc-related domain. The following questions therefore arise:

What is the exact extent and nature of these ophiolitic magmatic units: oceanic crust created at a mid-ocean ridge or back-arc oceanic lithosphere? Could part or all of the magmatic rocks initially attributed to the Cretaceous Harsin-Sahneh ophiolite belong to the Tertiary arc-domain?

(2)

How do the geochemistry of Eocene magmatic rocks from Kamyaran compare with the calc-alkaline magmatic rocks of the Mesozoic Sanandaj-Sirjan arc and the Eocene to Plio-Quaternary Urumieh-Dokhtar arc?

What are the implications for the evolution of the residual Tethyan oceanic realm and subduction processes, just before the Zagros convergence?

In this paper, we systematically compare the variation of major and trace elements of selected samples (Fig. 2c), with emphasis on those which ages are stratigraphically well-constrained, to characterise the magmatic rocks and their evolution with time. We use geochemical correlations for samples with undetermined ages, i.e., we consider the overall geochemical similarity of samples from similar structural units to be a strong argument in favour of them being coeval. For the sake of consistency, the distinction made by Braud (1987) between the two major areas of Harsin-Sahneh and Kamyaran is used below.

\section{Sample selection}

Forty-two magmatic rocks were sampled in the Harsin-Sahneh and Kamyaran regions (Fig. 2c).

\subsection{The Harsin-Sahneh region}

The part of the Kermanshah ophiolite allegedly related to the ophiolitic sequence by Braud (1987) comprises of:

Group A: Lava samples 157, 159, and 176, conformably overlain by pelagic sediments dated as Malm (Braud, 1987); samples 157 and 159 are clearly associated with radiolarites of Triassic to Liassic age. 
Group B: Four gabbros, i.e., samples 161, 165, 169, and 169b, spatially associated with the most extensive mantle peridotite outcrops. The samples were collected from gabbroic stocks within harzburgites that are intruded by basic dykes, i.e., samples 166 and 171 (see below). The gabbros are attributed to the ophiolitic Kuh-e-Shirez massif located to the North of Harsin, thrusted southward onto the Triassic-Liassic radiolarite unit related to samples 157 and 159 .

Group C: Five isolated dyke samples, previously interpreted as part of the Amleh Aliabad ophiolitic dyke complex (Braud, 1987), i.e., samples 172, 173, and 174, or as part of the Kuh e Shirez outcrops, i.e., samples 166 and 171.

Group D: Nine samples from large gabbroic and dioritic intrusions, along the Gamasiab River, intersecting a slice of granoblastic mantle harzburgites and across Paleocene andesitic lavas and folded beds of Paleocene limestone and Eocene flysch deposits (Fig. 3), north of the Harsin-Sahneh area, i.e., samples 206, 207, 208, 209, 212, and 213. Three gabbros, i.e., samples 178, 215, and 216, were sampled from a similar but smaller intrusion, though more deformed, further to the East near Hala Charrow. Lower Miocene limestones in the vicinity of Ali Abad unconformably overlie them. The presence of large harzburgite enclaves within the gabbro suggests that the large intrusion was emplaced through a peridotitic substratum.

\subsection{The Kamyaran region}

Selected samples from the west Kamyaran region belong to two groups:

Group E: Five basaltic or andesitic lavas, i.e., samples 181, 182, 183, 185, and 186, from tectonic slices interlayered with Paleocene sediments and highly deformed and serpentinised peridotites immediately to the West of Kamyaran, Ahangarän. The fossils present in rare limestone layers interstratified with the volcanic rocks consistently yield Paleocene ages ( Braud, 1987). Two additional samples of similar age come from the western Kamyaran region: sample 191 is a lava closely associated with a tuff, as is commonly found in Paleocene-lower Eocene sediments, whereas sample 194 belongs to the base of a Tertiary slice consisting of pillow-lavas associated with calcareous beds containing Globorotalia, which indicates a Paleocene-Lower Eocene age ( Braud, 1987).

Group F: Three gabbros, i.e., samples 189, 196, and 198, that intrudes the lavas listed above, and should therefore be considered as post-Paleocene.

Samples from the East and Central Kamyaran massif include:

Group G: Four lavas, i.e., samples 217, 220, 222, and 223 from the somewhat younger Eocene to Upper Eocene units of east Kamyaran. Samples 217 and 220 are associated with a flysch of Lutetian-Priabonian age.

Group H: Four diorites, i.e., samples 225, 226, 227, and 228, of probable Upper Eocene age. Dolerite dykes and small gabbroic stocks, i.e., samples 225 and 226, intersect the flysch and the volcano-sedimentary formations present in the east of Kamyaran. Sample 226, a granular cumulate rock, intrudes sample 225, a diorite. We regard them as Upper Eocene in age because of the intrusive character of sample 226 
and the absence of any flysch type sediment. In addition, they are located on top of the Tertiary unit. Samples 227 and 228 are gabbros from a magmatic breccia. They are located in close proximity to samples 225 and 226 and accordingly thought to be of the same age, i.e., Upper Eocene.

Group I: Three samples from the central part of this Kamyaran region, Kherra, i.e., samples 199, 200, and 201. Sample 199 is a microdiorite bordering sample 200 gabbro and is crosscut by a microgabbro dyke, i.e., sample 201, in the same Tertiary slice. Sample 199 closely resembles the volcanic rocks of samples 222 and 223 of presumed Paleocene-Lower Eocene age on chemical grounds while samples 200 and 201 are analogous to Upper Eocene volcanic samples 217 and 220.

\section{Petrographic description}

Microscopic mineral occurrences and textural characteristics are given in Table 1. Selected samples (Table 2) were analysed by electron microprobe analysis with Camebax SX50 and SX100 electron microprobes (Camparis Center at University Paris VI). The analytical conditions are: $15 \mathrm{kV}, 10 \mathrm{nA}$, WDS. The standards used are: $\mathrm{Fe}_{2} \mathrm{O}_{3}(\mathrm{Fe}), \mathrm{MnTiO}_{3}(\mathrm{Mn}, \mathrm{Ti})$, diopside $(\mathrm{Mg}, \mathrm{Si}), \mathrm{CaF}_{2}(\mathrm{~F})$, orthoclase $(\mathrm{Al}, \mathrm{K})$, anorthite $(\mathrm{Ca})$, and albite $(\mathrm{Na})$.

Table 1.

Mineral occurrences and the textural characteristics. Abbreviations: act: actinolite; amphi: amphibole; cc: calcite; chl: chlorite; cpx: clinopyroxene; ep: epidote; Fk: adularia; hbl: hornblende; ol: olivine; ox: oxide; pl: plagioclase; prh: prehnite; tr: tremolite; zeol: zeolite.

\begin{tabular}{|c|c|c|c|c|c|c|c|}
\hline Group & Sample & Age & Type & Texture & Igneous minerals & $\begin{array}{c}\text { Alteration } \\
\text { minerals }\end{array}$ & GPS coordinates \\
\hline a & 157 & Mesozoic & Lava harsin & Aphanitic & $\mathrm{pl}, \mathrm{cpx}, \mathrm{ox}$ & act/tre, cal, clay & $\begin{array}{l}\text { E } 47.513-\mathrm{N} \\
34.271\end{array}$ \\
\hline $\mathrm{a}$ & 159 & Mesozoic & Lava harsin & Aphanitic & $\mathrm{pl}, \mathrm{cpx}, \mathrm{ox}$ & cal, clay & $\begin{array}{l}\text { E } 47.695-\mathrm{N} \\
34.244\end{array}$ \\
\hline $\mathrm{a}$ & 176 & Mesozoic & Lava harsin & Oriented aphanitic & $\mathrm{pl}, \mathrm{cpx}, \mathrm{ox}$ & - & $\begin{array}{l}\text { E } 47.807-\mathrm{N} \\
34.378\end{array}$ \\
\hline b & 161 & Mesozoic & Gabbro harsin & Phaneritic & $\mathrm{pl}, \mathrm{cpx}, \mathrm{ox}$ & act/tremo, pre, cal & $\begin{array}{l}\text { E } 47.624-\mathrm{N} \\
34.320\end{array}$ \\
\hline $\mathrm{b}$ & 165 & Mesozoic & Gabbro harsin & Phaneritic & $\mathrm{pl}, \mathrm{cpx}, \mathrm{ox}$ & $\begin{array}{l}\text { act/tremo, cli, } \\
\text { clay }\end{array}$ & $\begin{array}{l}\text { E } 47.632-\mathrm{N} \\
34.372\end{array}$ \\
\hline $\mathrm{b}$ & 169 & Mesozoic & Gabbro harsin & Phaneritic cumulate & pl, cpx, ox & - & $\begin{array}{l}\text { E } 47.633-\mathrm{N} \\
34.374\end{array}$ \\
\hline $\mathrm{b}$ & $169 b$ & Mesozoic & Gabbro harsin & Phaneritic cumulate & $\mathrm{pl}, \mathrm{cpx}, \mathrm{ox}$ & - & - \\
\hline $\mathrm{c}$ & 166 & Eocene & Dyke gamasiab & Phaneritic equante & $\mathrm{pl}, \mathrm{ox}$ & - & - \\
\hline c & 171 & Eocene & Dyke gamasiab & Microlitic & pl, hbl, ox & epi & $\begin{array}{l}\text { E } 47.687-\mathrm{N} \\
34.398\end{array}$ \\
\hline
\end{tabular}




\begin{tabular}{|c|c|c|c|c|c|c|c|}
\hline & Sample & Age & Type & Texture & Igneous minerals & $\begin{array}{c}\text { Alteration } \\
\text { minerals }\end{array}$ & GPS coordinates \\
\hline c & 172 & Eocene & Dyke gamasiab & Microlitic & $\mathrm{pl}, \mathrm{hbl}, \mathrm{ox}$ & epi & $\begin{array}{l}\text { E } 47.687-\mathrm{N} \\
34.398\end{array}$ \\
\hline $\mathrm{c}$ & 173 & Eocene & Dyke gamasiab & Intersertal & $\mathrm{pl}, \mathrm{px}$ & act/tre, pre & $\begin{array}{l}\text { E } 47.687-\mathrm{N} \\
34.398\end{array}$ \\
\hline c & 174 & Eocene & Dyke gamasiab & Intersertal & $\mathrm{pl}, \mathrm{px}$ & act/tre, pre & $\begin{array}{l}\text { E } 47.687-\mathrm{N} \\
34.398\end{array}$ \\
\hline $\mathrm{d}$ & 178 & Mesozoic & Gabbro harsin & $\begin{array}{l}\text { Foliated } \\
\text { microphaneritic }\end{array}$ & $\mathrm{pl}, \mathrm{cpx}, \mathrm{ox}$ & acti/tremo, chl & $\begin{array}{l}\text { E } 47.839-\mathrm{N} \\
34.370\end{array}$ \\
\hline d & 206 & Eocene & Diorite gamasiab & Intersertal & $\mathrm{pl}$, hbl, magn & $\begin{array}{l}\text { qtz, chl, epi, cal, } \\
\text { pre }\end{array}$ & $\begin{array}{l}\text { E } 47.741-\mathrm{N} \\
34.410\end{array}$ \\
\hline d & 207 & Eocene & Diorite gamasiab & Intersertal & $\mathrm{pl}, \mathrm{hbl}, \mathrm{ox}$ & act/tremo, epi & $\begin{array}{l}\text { E } 47.741-\mathrm{N} \\
34.410\end{array}$ \\
\hline d & 208 & Eocene & Gabbro gamasiab & Ophitic to phaneritic & $\mathrm{pl}, \mathrm{hbl}, \mathrm{ox}$ & act/tre, pre, zeo & $\begin{array}{l}\text { E } 47.741-\mathrm{N} \\
34.410\end{array}$ \\
\hline $\mathrm{d}$ & 209 & Eocene & Diorite gamasiab & Phaneritic & $\mathrm{pl}$, hbl, magn & qtz, chl & $\begin{array}{l}\text { E } 47.741-\mathrm{N} \\
34.410\end{array}$ \\
\hline d & 212 & Eocene & Gabbro gamasiab & Phaneritic & $\mathrm{pl}, \mathrm{cpx}, \mathrm{ox}$ & - & $\begin{array}{l}\text { E } 47.713-\mathrm{N} \\
34.418\end{array}$ \\
\hline d & 213 & Eocene & Diorite gamasiab & Microphaneritic & $\mathrm{pl}, \mathrm{hbl}, \mathrm{ox}$ & act/tre, chl & $\begin{array}{l}\text { E } 47.713-\mathrm{N} \\
34.418\end{array}$ \\
\hline d & 215 & Eocene & Gabbro gamasiab & Phaneritic cumulate & $\mathrm{pl}, \mathrm{ol}, \mathrm{cpx}, \mathrm{ox}$ & - & $\begin{array}{l}\text { E } 47.844-\mathrm{N} \\
34.368\end{array}$ \\
\hline d & 216 & Eocene & Gabbro gamasiab & Phaneritic & $\mathrm{pl}, \mathrm{px}, \mathrm{ox}$ & - & $\begin{array}{l}\text { E 47.884-N } \\
34.358\end{array}$ \\
\hline e & 181 & Paleocene & Lava kamyaran & Microphaneritic & $\mathrm{pl}, \mathrm{cpx}, \mathrm{ox}$ & act/tre, chl & $\begin{array}{l}\text { E 46.924-N } \\
34.837\end{array}$ \\
\hline e & 182 & Paleocene & Lava kamyaran & Microphaneritic & $\mathrm{pl}, \mathrm{cpx}, \mathrm{ox}$ & act/tre, chl & $\begin{array}{l}\text { E 46.924-N } \\
34.837\end{array}$ \\
\hline e & 183 & Paleocene & Lava kamyaran & Shistose & $\mathrm{pl}, \mathrm{px}, \mathrm{ox}$ & act/tremo & $\begin{array}{l}\text { E } 46.951-\mathrm{N} \\
34.857\end{array}$ \\
\hline e & 185 & Paleocene & Lava kamyaran & $\begin{array}{l}\text { Foliated } \\
\text { microphaneritic }\end{array}$ & $\mathrm{pl}, \mathrm{hbl}$ & $\begin{array}{l}\text { epi, qtz, act/tre, } \\
\text { ox }\end{array}$ & $\begin{array}{l}\text { E } 46.951-\mathrm{N} \\
34.857\end{array}$ \\
\hline e & 186 & Paleocene & Lava kamyaran & Deformed intersertal & $\begin{array}{l}\text { pl-Ab, hbl, magn, } \\
\text { ox }\end{array}$ & act/tre, chl & $\begin{array}{l}\text { E } 46.951-\mathrm{N} \\
34.857\end{array}$ \\
\hline e & 191 & Paleocene & Volcanic kamyaran & Aphanitic fluidal & $\mathrm{pl}, \mathrm{px}, \mathrm{ox}$ & cal & - \\
\hline e & 194 & Paleocene & Volcanic kamyaran & Aphanitic porphy. & $\mathrm{pl}, \mathrm{px}, \mathrm{ox}$ & $\begin{array}{l}\text { act/tremo, chl, } \\
\text { clay }\end{array}$ & - \\
\hline $\mathrm{f}$ & 189 & Paleocene & Gabbro kamyaran & Phaneritic & $\mathrm{pl}, \mathrm{ol}, \mathrm{cpx}, \mathrm{hbl}, \mathrm{ox}$ & - & E $46.956-\mathrm{N}$ \\
\hline
\end{tabular}


Eocene

Lava kamyaran

Aphanitic porphy.

pl, amphi op

E 47.230-N

34.787

h

Eocene

Diorite kamyaran

Microphaneritic

$\mathrm{pl}, \mathrm{ox}$

Fk, chl, clay

E 47.196-N

34.826

Diorite kamyaran

Orthocumulate

pl, ox

Fk, chl, clay

E 47.196-N

34.826

E 47.178-N

34.839

E 47.178-N

34.839

act/tre kamyaran

pl, cpx, hbl, magn, $F k$

Phaneritic cumulate 
Table 2.

Electron microprobe analyses of selected representative minerals.

Samples $\mathrm{SiO}_{2} \mathrm{Al}_{2} \mathrm{O}_{3} \quad \mathrm{Cl} \mathrm{K}_{2} \mathrm{O} \mathrm{CaO} \mathrm{TiO}_{2} \mathrm{Cr}_{2} \mathrm{O}_{3} \mathrm{MnO} \mathrm{FeO} \mathrm{Na}_{2} \mathrm{O} \mathrm{MgO} \mathrm{Sum}$ Feldspars

$\begin{array}{lllllllllllll}158 & 67.86 & 20.41 & 0.08 & 0.09 & 0.67 & 0.06 & 0.00 & 0.03 & 0.76 & 11.73 & 0.19 & 101.87\end{array}$

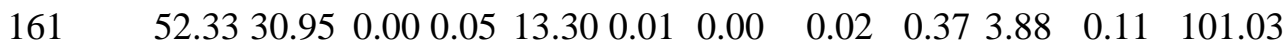

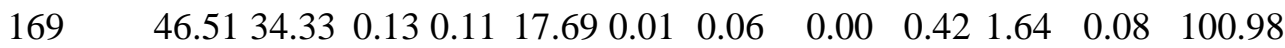

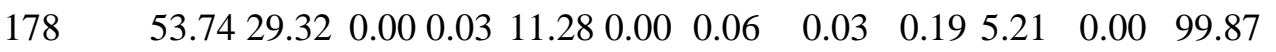

$\begin{array}{lllllllllllll}181 & 58.91 & 26.42 & 0.00 & 0.16 & 8.25 & 0.13 & 0.00 & 0.01 & 0.93 & 6.69 & 0.05 & 101.54\end{array}$

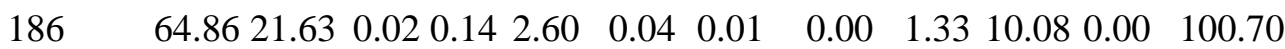

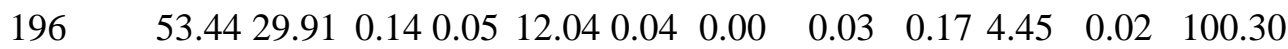

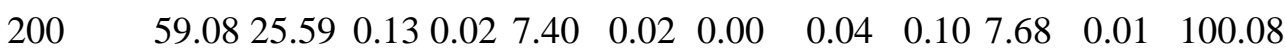

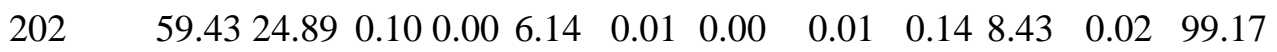

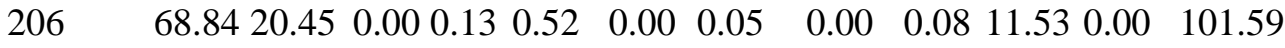

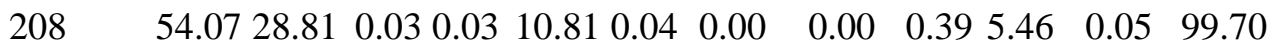

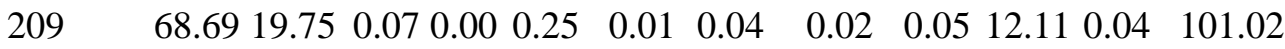

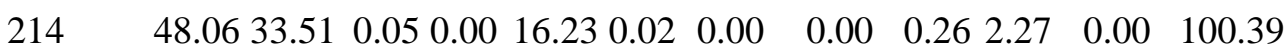

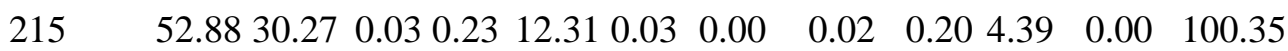

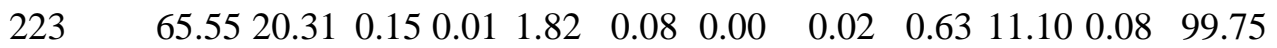

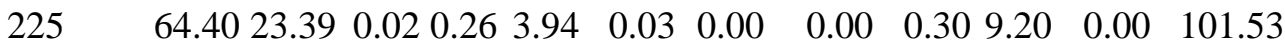

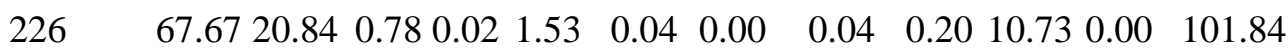

Samples $\mathrm{SiO}_{2} \mathrm{Al}_{2} \mathrm{O}_{3} \mathrm{Cl} \mathrm{K}_{2} \mathrm{O} \mathrm{CaO}^{\mathrm{TiO}_{2}} \mathrm{Cr}_{2} \mathrm{O}_{3} \mathrm{MnO}$ FeO $\mathrm{Na}_{2} \mathrm{O} \mathrm{MgO}$ Sum $\mathrm{Mg \#}$ Clinopyroxenes

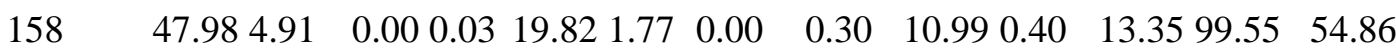

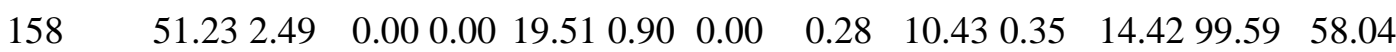




\begin{tabular}{|c|c|c|c|c|c|c|c|c|c|}
\hline Samples & $\mathrm{SiO}_{2} \mathrm{Al}_{2} \mathrm{O}_{3}$ & ${ }_{3} \mathrm{Cl} \quad \mathrm{K}_{2} \mathrm{O}$ & $\mathrm{CaO} \mathrm{TiO}_{2}$ & ${ }_{2} \mathrm{Cr}_{2} \mathrm{O}$ & ${ }_{3} \mathrm{MnO}$ & $\mathrm{FeO}$ & $\mathrm{Na}_{2} \mathrm{O}$ & MgO Sum & Mg\# \\
\hline 161 & 52.652 .66 & 0.000 .00 & 20.630 .86 & 0.08 & 0.22 & 6.67 & 0.40 & 15.8099 .97 & 70.32 \\
\hline 161 & 52.282 .59 & 0.020 .00 & 21.850 .91 & 0.22 & 0.14 & 6.22 & 0.31 & 15.3299 .85 & 71.14 \\
\hline 161 & 52.782 .88 & 0.000 .00 & 20.800 .98 & 0.25 & 0.12 & 6.12 & 0.38 & 15.5999 .90 & 71.82 \\
\hline 161 & 53.252 .70 & 0.000 .00 & 19.630 .59 & 0.16 & 0.24 & 6.51 & 0.35 & 16.1799 .60 & 71.28 \\
\hline 181 & 51.892 .45 & 0.000 .00 & 19.281 .09 & 0.07 & 0.19 & 10.25 & 0.29 & 14.84100 .34 & 59.14 \\
\hline 181 & 50.134 .74 & 0.010 .00 & 21.141 .77 & 0.11 & 0.13 & 8.18 & 0.38 & 13.84100 .43 & 62.86 \\
\hline 196 & 51.203 .14 & 0.010 .04 & 22.010 .89 & 0.36 & 0.16 & 6.33 & 0.41 & 15.63100 .17 & 71.17 \\
\hline 196 & 52.052 .54 & 0.040 .00 & 21.380 .81 & 0.12 & 0.26 & 6.31 & 0.32 & 15.4799 .30 & 71.03 \\
\hline 200 & 53.990 .64 & 0.060 .03 & 23.200 .10 & 0.08 & 0.24 & 7.65 & 0.50 & 13.83100 .31 & 64.40 \\
\hline 204 & 54.301 .95 & 0.020 .00 & 21.570 .04 & 1.23 & 0.01 & 1.57 & 1.35 & 16.8198 .86 & 91.44 \\
\hline 214 & 51.653 .18 & 0.000 .02 & 21.751 .33 & 0.82 & 0.19 & 5.88 & 0.24 & 14.98100 .05 & 71.83 \\
\hline 215 & 52.602 .90 & 0.040 .00 & 22.380 .70 & 0.11 & 0.13 & 5.67 & 0.49 & 15.31100 .32 & 72.97 \\
\hline 215 & 52.493 .63 & 0.000 .02 & 21.740 .88 & 0.07 & 0.00 & 5.84 & 0.44 & 15.54100 .65 & 72.67 \\
\hline
\end{tabular}

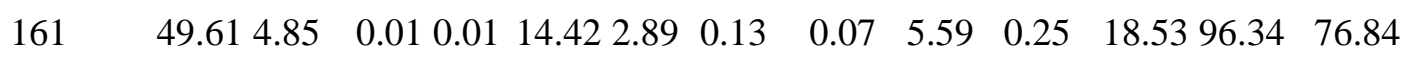

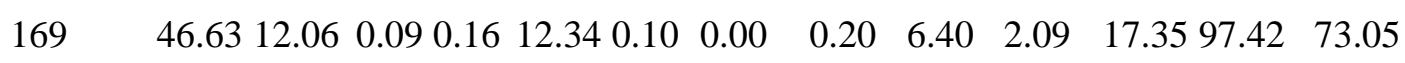

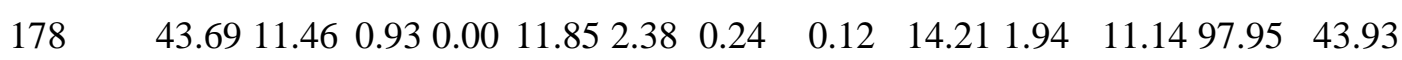

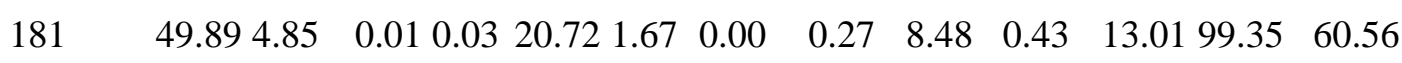

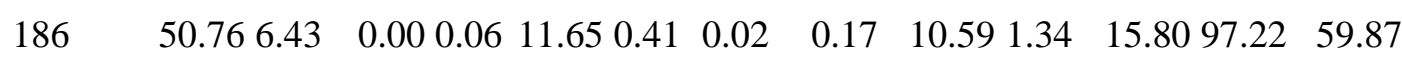

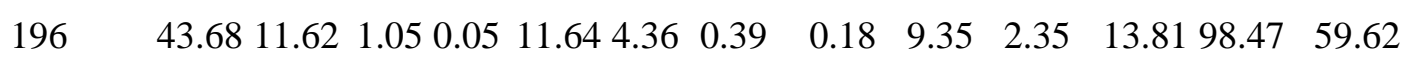

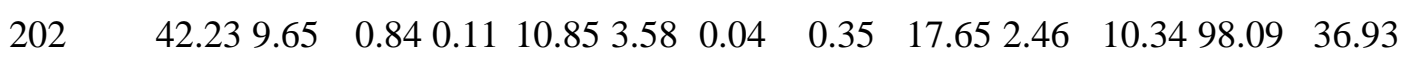

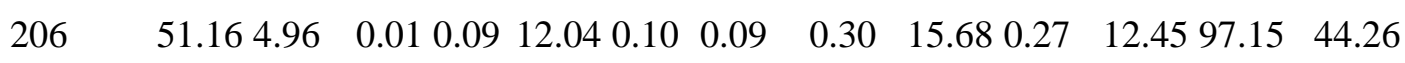

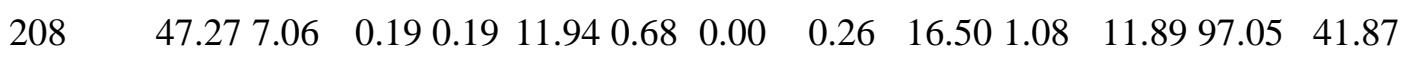

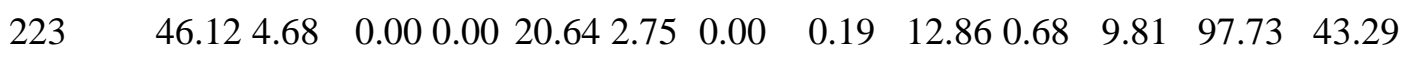




\begin{tabular}{|c|c|c|c|c|c|c|c|c|c|c|c|}
\hline Samples & $\mathrm{SiO}_{2} \mathrm{Al}_{2} \mathrm{O}_{3}$ & $\mathrm{Cl} \quad \mathrm{K}_{2} \mathrm{O}$ & $\mathrm{CaO}$ & $\mathrm{TiO}_{2}$ & $\mathrm{Cr}_{2} \mathrm{C}$ & MnC & $\mathrm{FeO}$ & $\mathrm{Na}_{2} \mathrm{C}$ & MgO & Sum & Mg\# \\
\hline 226 & 46.975 .48 & 0.850 .36 & 10.27 & 0.99 & 0.00 & 0.59 & 22.70 & 1.66 & 8.86 & 98.72 & 28.07 \\
\hline \multicolumn{12}{|l|}{ Olivines } \\
\hline 196 & 38.170 .03 & 0.000 .00 & 0.25 & 0.01 & 0.00 & 0.50 & 25.56 & 60.03 & 35.18 & 399.72 & 57.92 \\
\hline 196 & 38.420 .01 & 0.000 .01 & 0.05 & 0.06 & 0.00 & 0.33 & 25.68 & 0.01 & 35.34 & 499.90 & 57.91 \\
\hline 196 & 38.460 .00 & 0.000 .00 & 0.08 & 0.00 & 0.04 & 0.23 & 24.54 & 0.04 & 36.03 & 399.41 & 59.49 \\
\hline 204 & 41.190 .02 & 0.000 .00 & 0.03 & 0.03 & 0.06 & 0.09 & 8.54 & 0.00 & 49.97 & 799.92 & 85.40 \\
\hline 204 & 41.600 .08 & 0.030 .00 & 0.00 & 0.00 & 0.06 & 0.14 & 8.84 & 0.01 & 48.96 & 599.72 & 84.71 \\
\hline 204 & 41.680 .00 & 0.000 .00 & 0.01 & 0.01 & 0.00 & 0.25 & 8.61 & 0.01 & 49.45 & 5100.01 & 85.18 \\
\hline
\end{tabular}

Spinels

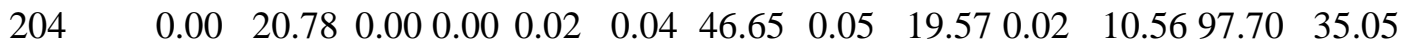

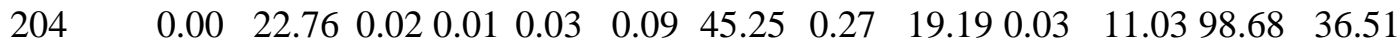

\subsection{Peridotites}

The peridotites sampled between Harsin and Sahneh and in a slice within the Eocene gabbro of the Gamasiab River are mainly harzburgites and composed of olivine $\left(\mathrm{Fo}_{85}\right)$, orthopyroxene, and chromium spinel. They generally exhibit a granoblastic texture with large (up to $7 \mathrm{~mm}$ in size), often rounded, olivine $\left(\mathrm{Fo}_{85}\right)$, enstatite $(1-2 \mathrm{~mm}$ in size), and two types of clinopyroxene as isolated grains (up to $4 \mathrm{~mm}$ in size) with reaction rims or as small euhedral grains. Chromite is present as a scattered accessory mineral (approximately $1 \mathrm{~mm}$ in size). The presence of kink-bands in olivine, orthopyroxene, and the largest clinopyroxene (Fig. 4a) is indicative of high temperature plastic mantle deformation (Nicolas et al., 1980). In some tectonic units (zone of Ahangarän), andesitic lavas directly overlie harzburgites. In the Kamyaran region, they exhibit a porphyroclastic texture, consisting of elongated orthopyroxene porphyroclasts cemented by small grains of olivine, orthopyroxene, and spinel. These harzburgites contain few dunitic patches. The serpentinisation of peridotites is variable, ranging from $10 \%$ to $70 \%$. 

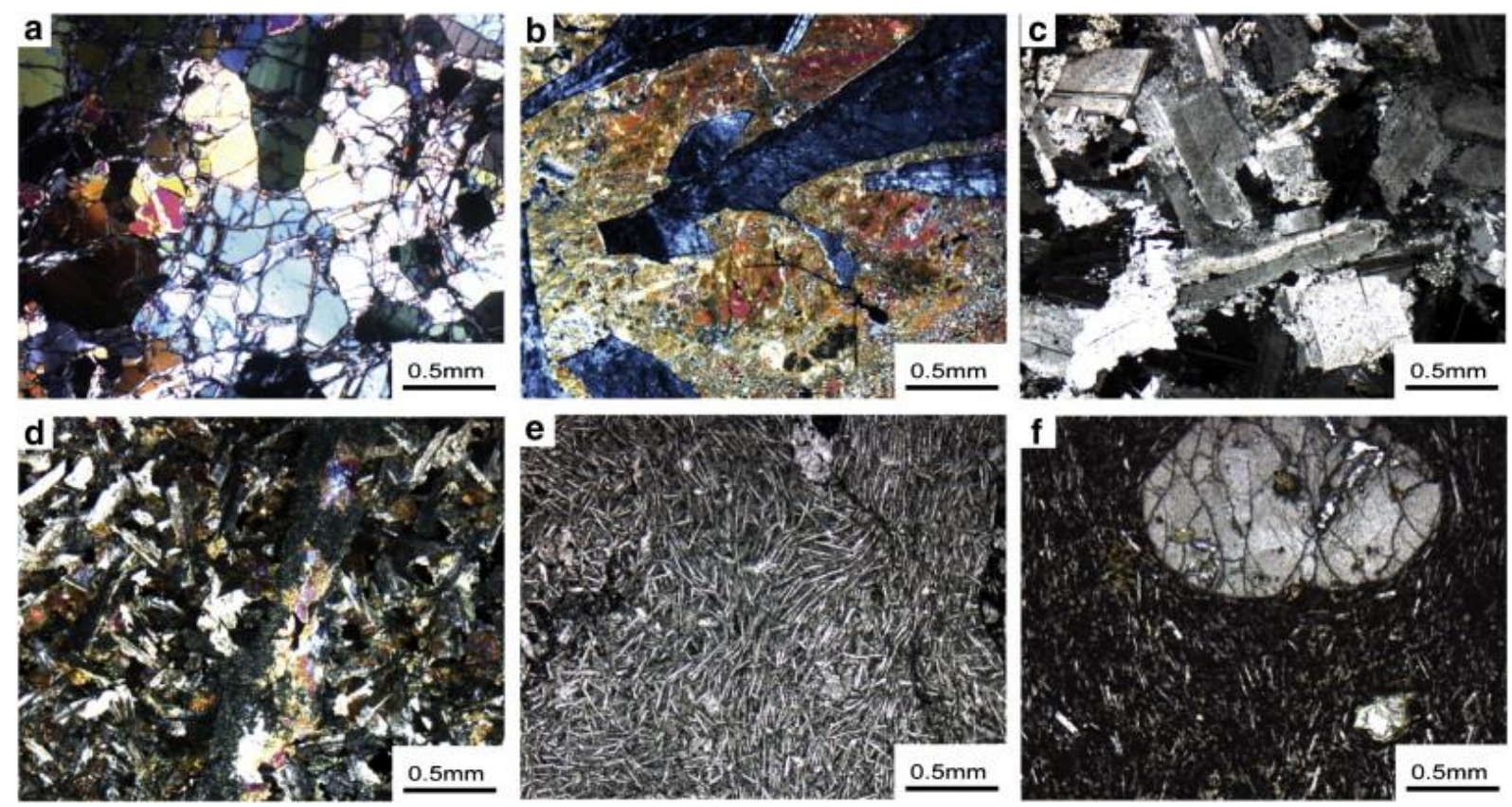

Fig. 4.

Thin section photomicrographs in crossed polarised light (a to $d$ and $f$ ) and plain polarised light (e): (a) Harzburgite with the presence of gliding systems in olivine (upper centre part), (b) phaneritic adcumulate textured gabbro with poikilitic clinopyroxene, (c) phaneritic textured diorite, (d) intersertal textured dyke with prehnite vein, (e) aphanitic textured basalt with fluidal disposition of plagioclase, and (f) aphanitic textured basalt with clinopyroxene porphyroclasts.

Large corroded diopsidic residual clinopyroxenes exhibit relatively high $\mathrm{Al}_{2} \mathrm{O}_{3}$ and low $\mathrm{TiO}_{2}$ contents (> 3\% and $\sim 0.04 \mathrm{wt} \%$, respectively). The low Ti content suggests a high degree of partial melting (Pearce and Norry, 1979), most likely implying a second stage melting of the mantle source (Hebert and Laurent, 1990). On the other hand, the small diopsidic clinopyroxenes are $\mathrm{Al}_{2} \mathrm{O}_{3}$ poor $(<2 \%)$, most likely crystallised from a percolating magma. Composition of the spinel in these peridotites is relatively constant (not shown). They show high $\mathrm{Cr}$ numbers $(\mathrm{Cr} /[\mathrm{Cr}+\mathrm{Al}])$, low Ti content, and low $\mathrm{Mg}$ number $<40(\mathrm{Mg} /[\mathrm{Mg}+\mathrm{Fe}])$, comparable to those of supra-subduction harzburgite or dunite (Ichii et al., 1992). The high $\mathrm{Cr}$ number suggests a high degree of partial melting (Dick and Bullen, 1984), confirming the depleted nature of the host peridotites.

\subsection{Gabbros}

The sampled gabbros are variable in texture and composition. Crystal size ranges from finegrained to pegmatitic within a single intrusion. These gabbros are occasionally and locally affected by foliation, mainly outlined by amphibole along shear zones. Layered gabbros that are typically observed in conventional ophiolites (e.g., Oman: Nicolas, 1989) were not observed. The coarse-grained gabbros ( Fig. 4b) exhibit ad- to mesocumulate texture with large crystals of (sometimes poikilitic) clinopyroxene, plagioclase (bytownite to labradorite, up to $5 \mathrm{~mm}$ to $1 \mathrm{~cm}$ in size), and rare olivine $\left(\mathrm{Fo}_{60}\right)$. Clinopyroxene in the gabbros displays chemical composition ranging from diopside to augite very similar to that of clinopyroxene of back-arc basin magmatic rocks with relatively high $\mathrm{Al}$ and low $\mathrm{Ti}$ and $\mathrm{Cr}$ contents ( Huot et al., 2002). Prismatic primary dark green hornblende (high temperature Fe-pargasitic 
hornblende to Mg-hornblende) was observed in the gabbros from the Gamasiab River and Kamyaran region. These primary amphiboles are intimately associated with abundant magnetite and ülvospinels. This mineralogical composition represents a marked difference from the main gabbroic sequence of typical ophiolites, where amphibole and oxide are only present in the upper isotropic gabbros. The crystal interfaces in the gabbros are often planar and sometimes lobate with numerous triple junctions, indicating equilibrium crystallisation. These textures suggest in situ liquid crystallisation.

In some places, these gabbros are highly foliated with clinopyroxene porphyroclasts within a mylonitic amphibole-bearing matrix, suggesting intense shearing of these intrusions. The microgabbros at the margins of coarse gabbroic intrusions exhibit an ophitic texture with plagioclase, clinopyroxene, amphibole and oxide. The secondary minerals are mainly actinolite and epidote crystallised under high temperature greenschist facies conditions. Smectite, and, in sample 200, adularia, crystallised at lower temperature.

\subsection{Diorites}

The diorite group consists of plutonic rocks with $\mathrm{SiO}_{2}$ ranging from 55 wt. $\%$ and 66 wt.\%. Their textures are mainly granular to microgranular. Plagioclase (4-5 mm long) often exhibits normal zonation patterns (andesine core to albite rim) and, in some cases, inverse zoning (Fig. 4c). Amphibole (ferro-pargasite to edenite) is observed between plagioclase laths. No primary quartz is observed in the most silica-rich diorite (sample 209). The secondary minerals in the diorite are mainly chlorite and actinolite, typical of high temperature hydrothermal metamorphism under greenschist facies conditions. Samples 225 and 226 contain smectite and adularia, characteristic of low temperature hydrothermal alteration.

\subsection{Dykes}

The dykes occur between Harsin and Sahneh, as isolated features or as swarms, crosscutting harzburgites or gabbros. No true sheeted dyke complex, with dykes nested within dykes as observed in Oman or Troodos, exists in the Kermanshah ophiolites. The texture of the dykes is fine grained and intersertal (Fig. 4d). Actinolitic amphibole encloses laths of altered plagioclase that have been transformed to phyllosilicate mineral, calcite, zeolite, epidote, or albite, depending on the degree of hydrothermal alteration. Dispersed ilmenite $\left(52 \mathrm{wt} . \% \mathrm{TiO}_{2}\right)$ occurs in all of the dykes. The presence of epidote and prehnite veins points to hydrothermal circulation. The most silica rich dyke (Sample 166) consists of only plagioclase (oligoclase), few amphiboles and ilmenite with a mosaic texture.

\subsection{Volcanic rocks}

The three Triassic to Liassic lava samples from the Harsin-Sahneh region contain unzoned plagioclase, clinopyroxene and oxide. No primary amphibole is observed in these Early Mesozoic rocks. Tremolite and actinote are the main secondary minerals.

The Paleocene to Eocene lavas in the Kamyaran area are characterised by the presence of abundant and often rimmed plagioclase, clinopyroxene, oxide, and primary amphibole in some samples. Plagioclase exhibits normal zoning with oligoclase to andesine cores and albitic rims. In some samples, the microlites show a viscous flow pattern (Fig. 4e). When present, augitic clinopyroxene (high $\mathrm{Al}$, low $\mathrm{Ti}$, typical of the arc environment) is associated with plagioclase microlites in a fine intersertal texture (Fig. 4f). Amphibole, when primary, is 
a Mg-hornblende. Ilmenite (approximately $50 \mathrm{wt} . \% \mathrm{TiO}_{2}$ ) is typically present. The most evolved lavas are composed mainly of plagioclase together with amphibole and oxide, but no pyroxene. The presence of zoned plagioclase, primary amphibole, and abundant Fe-Ti oxide, together with the presence of numerous vesicles, in these Paleocene-Eocene lavas distinguish them fundamentally from mid-ocean ridge basalts (MORB). These characteristics are more typical of calc-alkaline subduction related lavas.

Most of the volcanic rocks show evidence of hydrothermal interaction. Hydrothermal alteration of these lavas varies from $10 \%$ to approximately $50 \%$. These secondary minerals either replace the primary ones or fill veins or numerous vesicles that are the result of strong outgassing of the lavas. The presence of albite, chlorite, epidote, and fine amphibole are typical of greenschist facies conditions of hydrothermal metamorphism. Secondary minerals such as smectite, zeolite, prehnite, and calcite crystallised at lower temperatures. No massive sulphide deposit has been detected in these volcanic rocks.

\section{Geochemistry}

We present the geochemical characterization of magmatic rocks that have previously been mainly associated either with ophiolites in the southeastern region of Harsin-Sahneh or an Eocene arc in the northwest region of Kamyaran (Braud, 1987 and Leterrier, 1985). In the following sections, the major and trace element distributions are discussed in terms of lithological units and ages of the magmatic rocks. Major element analysis is presented only for 39 samples, those with a loss on ignition (LOI) lower than $3 \mathrm{wt} . \%$, to avoid hydrothermal metasomatic effects on the geochemical composition. The trace elements, which are less sensitive to hydrothermal alteration, are presented for all samples. These elements are key in characterising the magma source and answering the following questions: do MORB-type ophiolites exist in the Kermanshah area? Does the calc-alkaline magmatism correspond to a fore-arc, an arc or a back-arc environment?

\subsection{Analytical methods for major and trace elements}

The samples were analysed at Ecole et Observatoire des Sciences de la Terre in Strasbourg (France). An aliquot of each sample was crushed and powdered for $20 \mathrm{~min}$ with an electric mortar made of agate to avoid contamination. About $1 \mathrm{~g}$ was dried at $110{ }^{\circ} \mathrm{C}$ and burnt at $1000{ }^{\circ} \mathrm{C}$ for $3 \mathrm{~h}$ for chemical preparation. A $100 \mathrm{mg}$ fraction of each sample was then mixed with $750 \mathrm{mg}$ lithium tetraborate in a vitreous graphite crucible. The mixture was later amalgamated at $1000{ }^{\circ} \mathrm{C}$ in a silica-muffle furnace under an atmospheric pressure of argon for $30 \mathrm{~min}$. After cooling, the pearl obtained was directly dissolved in a crucible containing a diluted nitric acid and glycerine. The dissolution occurred at a temperature of $70{ }^{\circ} \mathrm{C}$. The final dilution was $4 \mathrm{~g} / \mathrm{l}$ (100 $\mathrm{mg}$ of sample in $25 \mathrm{ml}$ of solution). After filtering, the 4-g/l solution was directly analysed by ion condensed plasma-electric spectrometry. The same solution was diluted 10 times before ion condensed plasma-mass spectrometry measurements. The calibration curves were determined with five solutions: a blank one (750 mg lithium tetraborate that was amalgamated and dissolved in solution) and four international standards of Centre de Recherches Pétrographiques et Géochimiques (Nancy, France): AN-G, BEN, GS-N and VS-N. The standards were placed in the sample sequence every six samples to control the possible drift of the spectrometer and to refine the calibration. 
The geochemical data on multi-elementary diagrams were normalised with respect to the chondrite (McDonough and Sun, 1995) and primitive mantle values (Sun and McDonough, 1989). The geochemical results are shown in Table 3.

Table 3.

Major and trace element data for all study samples $(n=42)$.

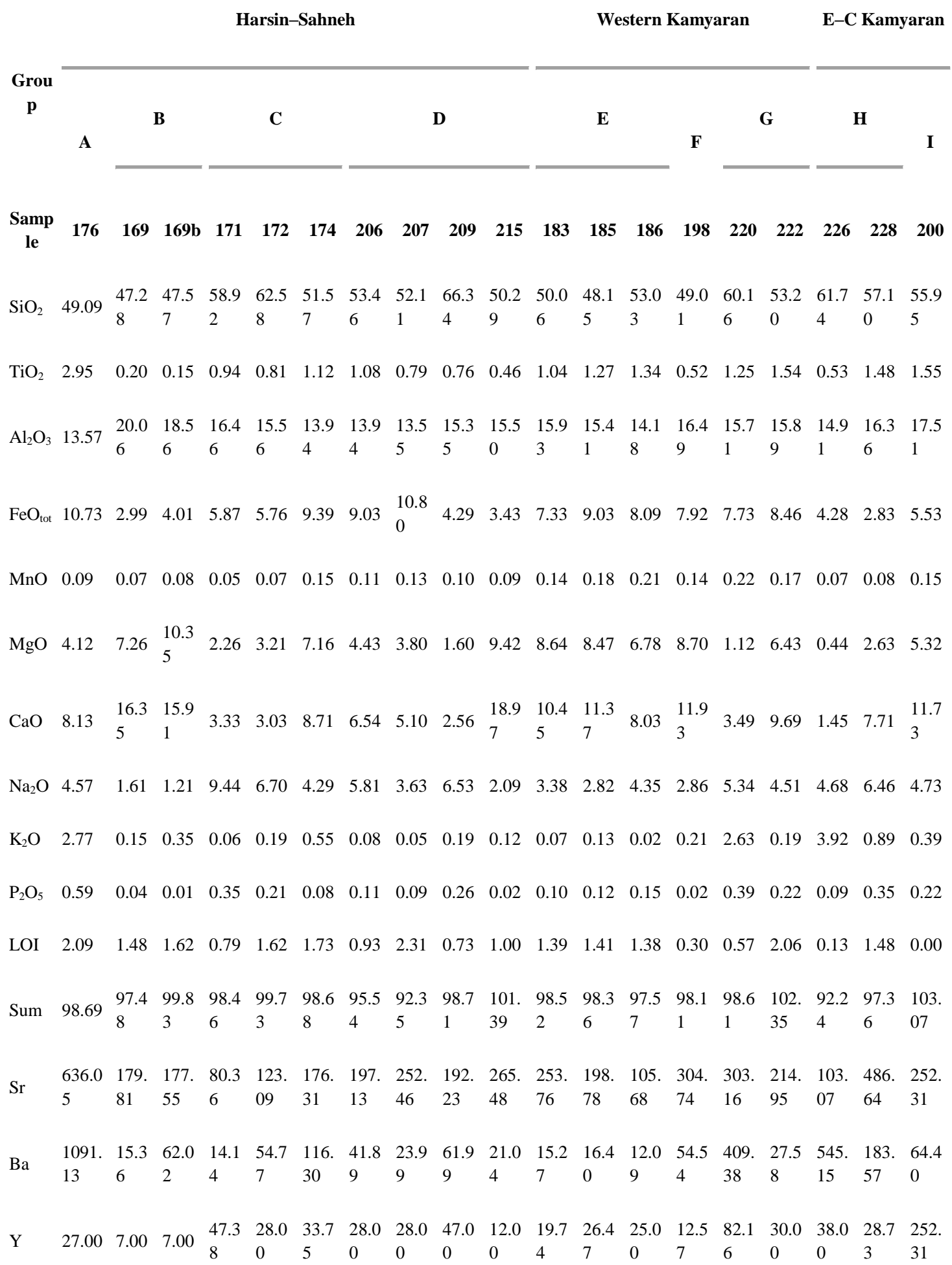




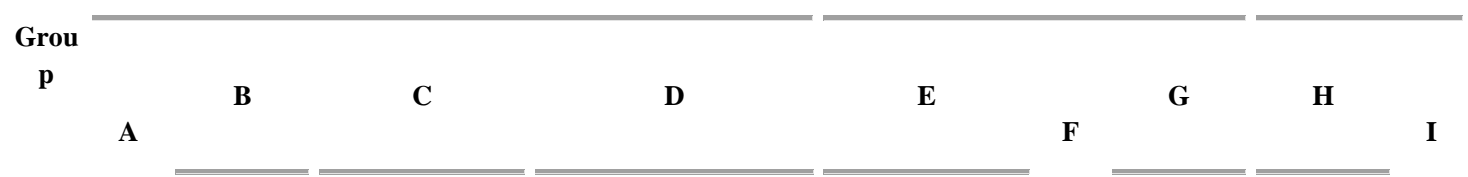

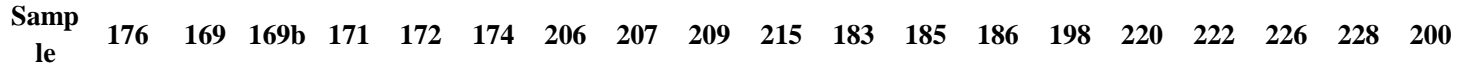

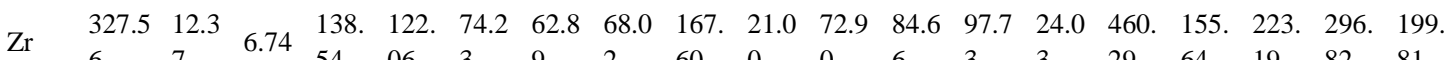

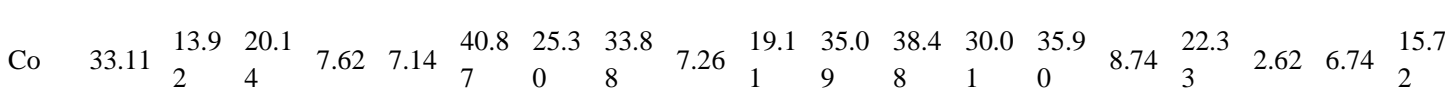

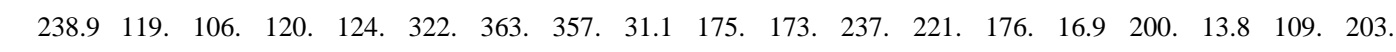
$\begin{array}{llllllllllllllllllllll}\mathrm{V} & 8 & 28 & 90 & 34 & 86 & 98 & 18 & 01 & 6 & 28 & 39 & 37 & 08 & 52 & 1 & 33 & 6 & 80 & 33\end{array}$

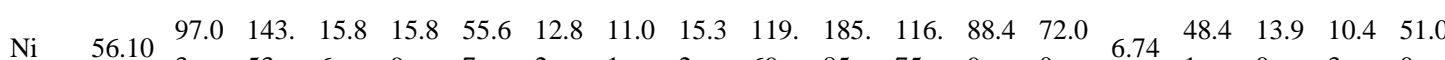

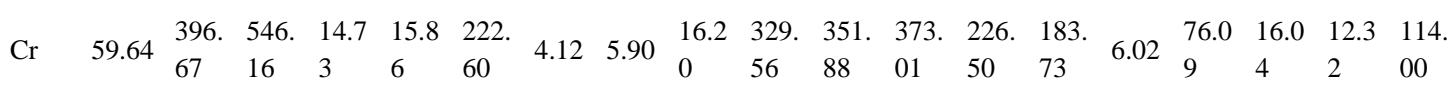

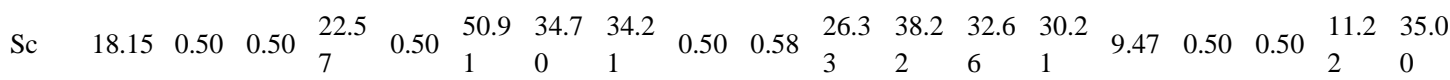

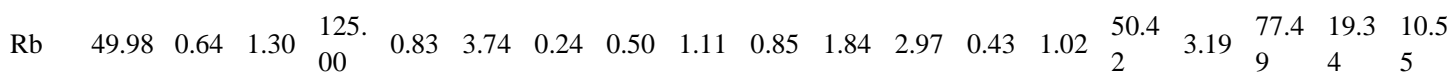
$\begin{array}{llllllllllllllllllll}\mathrm{Nb} & 62.44 & 0.15 & 0.00 & 2.34 & 2.67 & 0.60 & 0.34 & 0.72 & 3.95 & 0.00 & 0.85 & 3.16 & 4.60 & 0.13 & 0 & 5.32 & 5 & 0 & 6.36\end{array}$

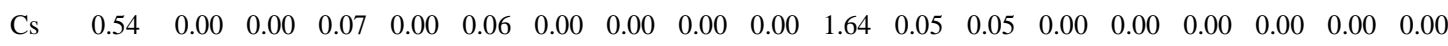

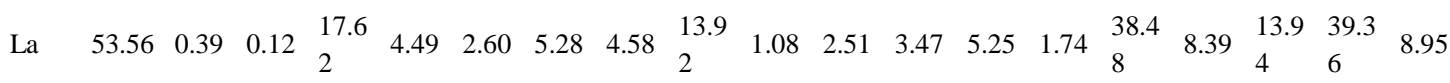

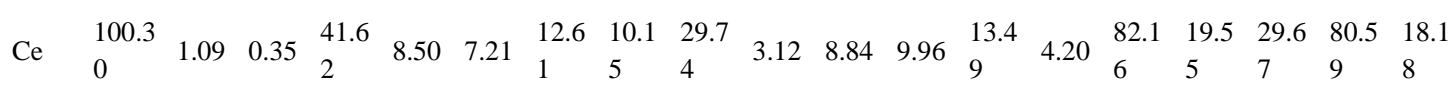
$\begin{array}{llllllllllllllllllll}\operatorname{Pr} & 11.59 & 0.18 & 0.07 & 5.44 & 1.19 & 1.30 & 1.94 & 1.50 & 4.11 & 0.60 & 1.61 & 1.65 & 2.08 & 0.65 & 10.5 & 2.78 & 3.76 & 8.81 & 2.39\end{array}$

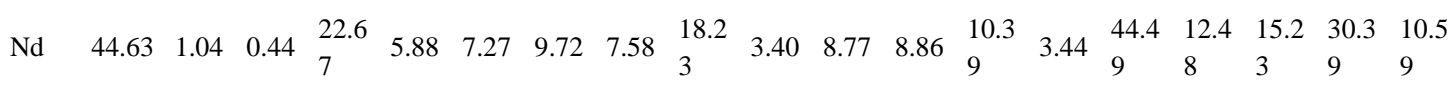
$\begin{array}{llllllllllllllllllll}\mathrm{Sm} & 8.72 & 0.44 & 0.20 & 5.63 & 1.87 & 2.95 & 3.18 & 2.43 & 5.03 & 1.39 & 2.91 & 3.00 & 3.22 & 1.15 & 0 & 3.40 & 3.77 & 5.57 & 2.96\end{array}$ $\begin{array}{llllllllllllllllllll}\mathrm{Eu} & 2.85 & 0.23 & 0.15 & 2.16 & 0.62 & 1.05 & 1.75 & 0.95 & 1.35 & 0.60 & 1.23 & 1.16 & 1.18 & 0.83 & 2.89 & 1.11 & 1.03 & 2.63 & 0.99\end{array}$

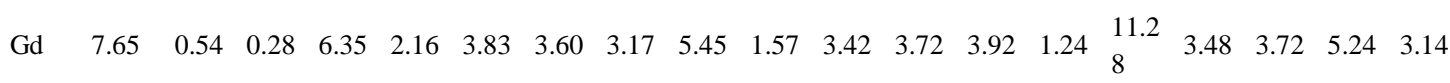

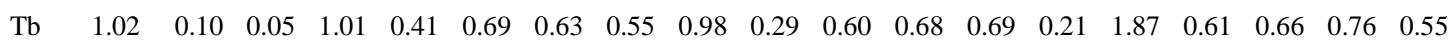
$\begin{array}{llllllllllllllllllll}\text { Dy } & 5.76 & 0.88 & 0.45 & 7.06 & 3.05 & 5.00 & 4.61 & 4.11 & 6.77 & 2.06 & 4.01 & 4.73 & 4.70 & 1.52 & 13.0 & 4.09 & 4.66 & 4.87 & 3.74\end{array}$ 


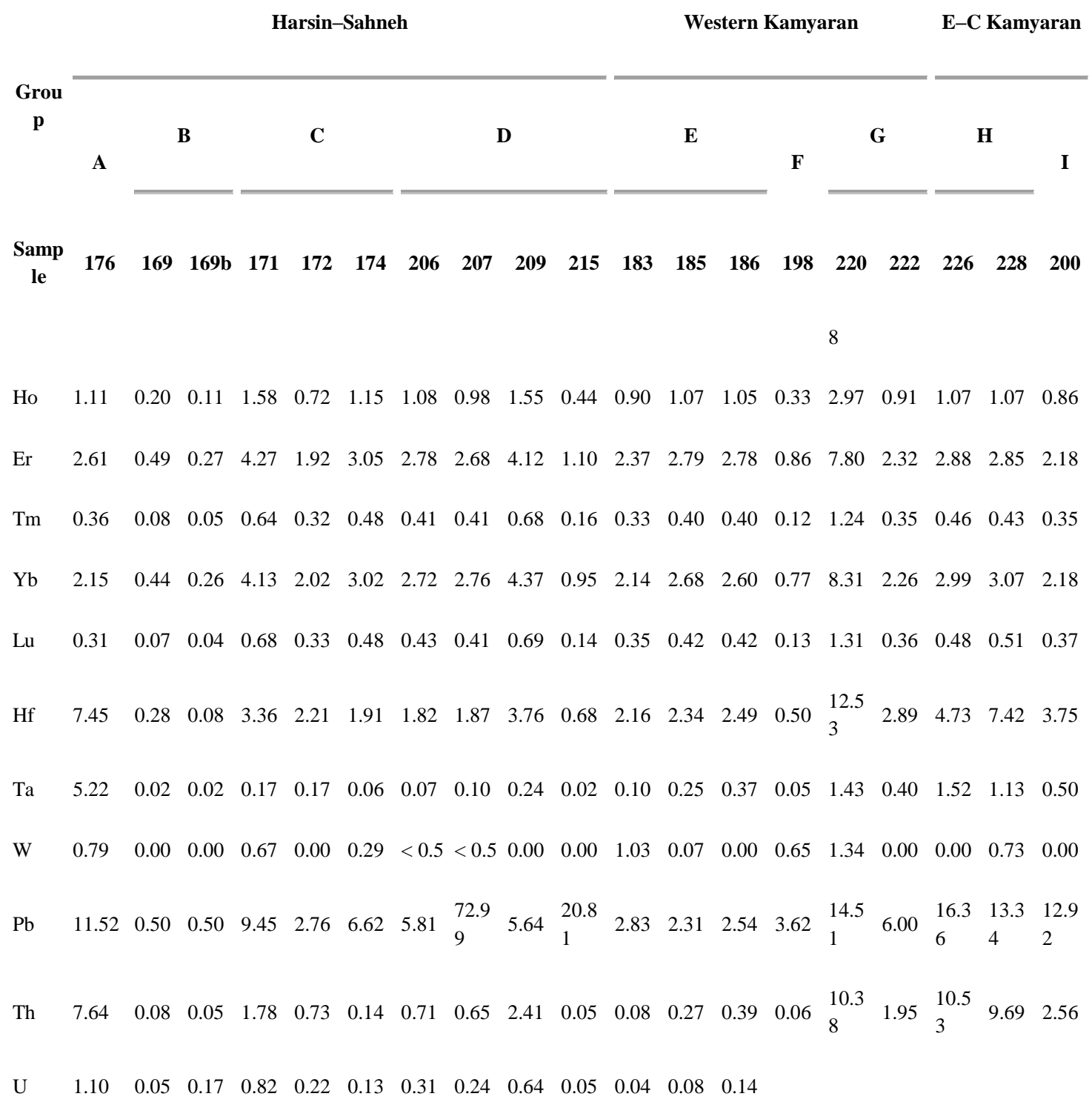

\subsection{Major elements}

\subsubsection{TAS and AFM diagrams}

In this section, to minimise potential hydrothermal effects, only 39 samples with a LOI lower than 3 wt.\% (Table 3) were selected for major element interpretation.

In the total alkali $\left(\mathrm{Na}_{2} \mathrm{O}+\mathrm{K}_{2} \mathrm{O}\right.$, wt.\%) versus $\mathrm{SiO}_{2}$ diagram (TAS diagram; Cox et al., 1979; Fig. 5a), the three samples assumed to belong to the Harsin ophiolite and associated with Triassic to Jurassic radiolarites (Group A) show a distinct alkaline character of basanites. The composition of the samples of Kamyaran lavas with a Paleocene age (Group E and F) range from basaltic to andesitic ( Fig. 5a), whereas the composition of the samples from the same area with an Eocene age (Group G) range from andesitic to latitic ( Fig. 5a). The HarsinSahneh dykes (Group C), which are also considered to be ophiolitic, exhibit a wide range of compositions from low-K basalt to latite, overlapping those of the Kamyaran Eocene magmatic rocks (Group $\mathrm{G}$ and $\mathrm{H}$ ). The Eocene gabbros from the Gamasiab Valley (Group D) range from gabbros to granodiorites. 

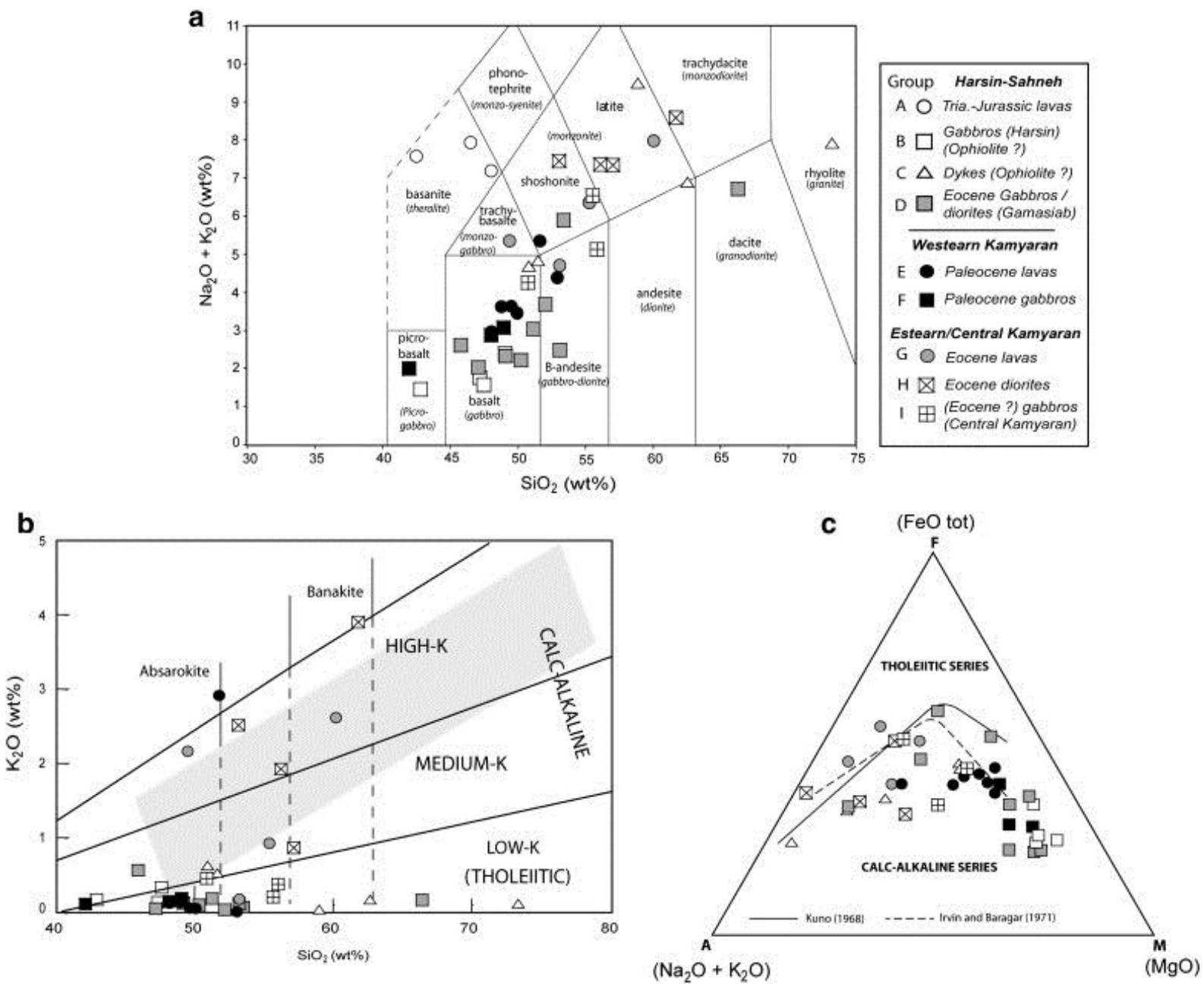

Fig. 5.

(a) Total alkali versus $\mathrm{SiO}_{2}$ (TAS, wt.\%) diagram. The samples were divided in two regions: Harsin (open symbols), considered to be ophiolitic ( Braud, 1987), and Kamyaran Paleocene (black symbols) and Eocene (grey symbols) magmatic rocks belonging to the arc. (b) AFM diagram with two calc-alkaline trends (alkaline Triassic to Liassic samples are not represented). (c) $\mathrm{K}_{2} \mathrm{O}$ versus $\mathrm{SiO}_{2}$ (wt.\%) diagram showing the low-K, medium-K to high-K calc-alkaline series and the range of the Umurieh-Doghtar and Sanandaj-Sirjan arc compositions (grey domain; alkaline Triassic to Liassic samples are not represented).

In the $\mathrm{K}_{2} \mathrm{O}$ versus $\mathrm{SiO}_{2}$ diagram ( Fig. 5b), the gabbros of the central and southern part of Harsin-Sahneh, assumed to be ophiolitic (Group B), fall in the low-K tholeiitic field. The Eocene gabbros and diorites from the northern part of the Harsin-Sahneh region and one lava and one gabbro from the Kamyaran area (Group I) exhibit low-K compositions, whereas most of the Eocene gabbros and diorites together with the lavas of the eastern and central part of the Kamyaran region (Group G, H and I) range from medium to high-K calc-alkaline. The Eocene volcanic rocks and most of the Eocene plutonic rocks (Group $\mathrm{G}$ and $\mathrm{H}$ ) fall within the calc-alkaline domain ( Fig. 5c), whereas most of the Paleocene lavas and gabbros (Group E and F) and the dykes (Group C) are plot in the tholeiitic field.

In the AFM diagram (Fig. 5b), samples representing liquid compositions (Eocene and Paleocene lavas of Groups $\mathrm{E}$ and $\mathrm{G}$ and dykes of Group $\mathrm{C}$ ), together with the plutonic rocks 
fall on a calc-alkaline trend. Most plutonic rocks from Harsin-Sahneh are MgO-rich, whereas the other diorites and gabbros together with the Paleocene and Eocene lavas plot mainly in the calc-alkaline domain from relatively $\mathrm{MgO}$-rich to relatively alkaline-rich lavas. A clear distinction between the Paleocene and Eocene Kamyaran samples, as noted above, is again apparent in this diagram.

\subsubsection{Major elements versus $\mathrm{SiO}_{2}$ diagrams}

The Mg numbers of these magmatic rocks are between 0.82 in the gabbros and 0.20 in the most evolved Eocene lavas. Among the dykes and lavas, which are thought to represent liquid compositions, the range of $\mathrm{Mg}$ numbers, though more restricted (between 0.58 and 0.20), confirms that these liquids underwent fractional crystallisation.

In the Harker diagrams (Fig. 6a), the three Triassic to Jurassic alkaline basanites, characterised by high $\mathrm{TiO}_{2}, \mathrm{P}_{2} \mathrm{O}_{5}$ and low $\mathrm{MgO}$, are excluded from almost all correlations. Inverse $\left(\mathrm{MgO}, \mathrm{FeO}, \mathrm{CaO}\right.$, and $\left.\mathrm{TiO}_{2}\right)$ and positive $\left(\mathrm{Na}_{2} \mathrm{O}\right.$ and $\left.\mathrm{P}_{2} \mathrm{O}_{5}\right)$ correlations can be drawn among the Harsin-Sahneh volcanic rocks and dykes, the Western Kamyaran PaleoceneEocene lavas and the Eastern and Central Kamyaran gabbros, particularly for the most silicarich samples $\left(\mathrm{SiO}_{2}>52 \%\right)$. The Harsin-Sahneh presumed ophiolitic gabbro and one of the Paleocene Kamyaran gabbros present poor correlations between the major elements and $\mathrm{SiO}_{2}$. They exhibit lower silica content and significantly higher $\mathrm{Al}_{2} \mathrm{O}_{3} \mathrm{MgO}$, and $\mathrm{CaO}$ content when compared to the Eocene gabbros and diorites. The higher $\mathrm{Al}_{2} \mathrm{O}_{3}$ together with high $\mathrm{CaO}$ content could be a result of the original calc-alkaline signature of the magma. However, repeated plagioclase accumulation could have led to the same effect. The high $\mathrm{Al}$ content of the clinopyroxene of these gabbros (Table 2) compared to those of the MOR-gabbros would also suggest a calc-alkaline origin for these gabbroic magmas. The dykes, Eocene gabbros and diorites exhibit a negative correlation for $\mathrm{MgO}, \mathrm{CaO}$, and $\mathrm{FeO}$ (most likely disrupted by oxide crystallisation) and a positive correlation for $\mathrm{Na}_{2} \mathrm{O}, \mathrm{P}_{2} \mathrm{O}_{5}$, and to some extent $\mathrm{TiO}_{2}$ (again, disrupted by oxide crystallisation) with $\mathrm{SiO}_{2} . \mathrm{Al}_{2} \mathrm{O}_{3}$ is relatively constant as $\mathrm{SiO}_{2}$ increases. 

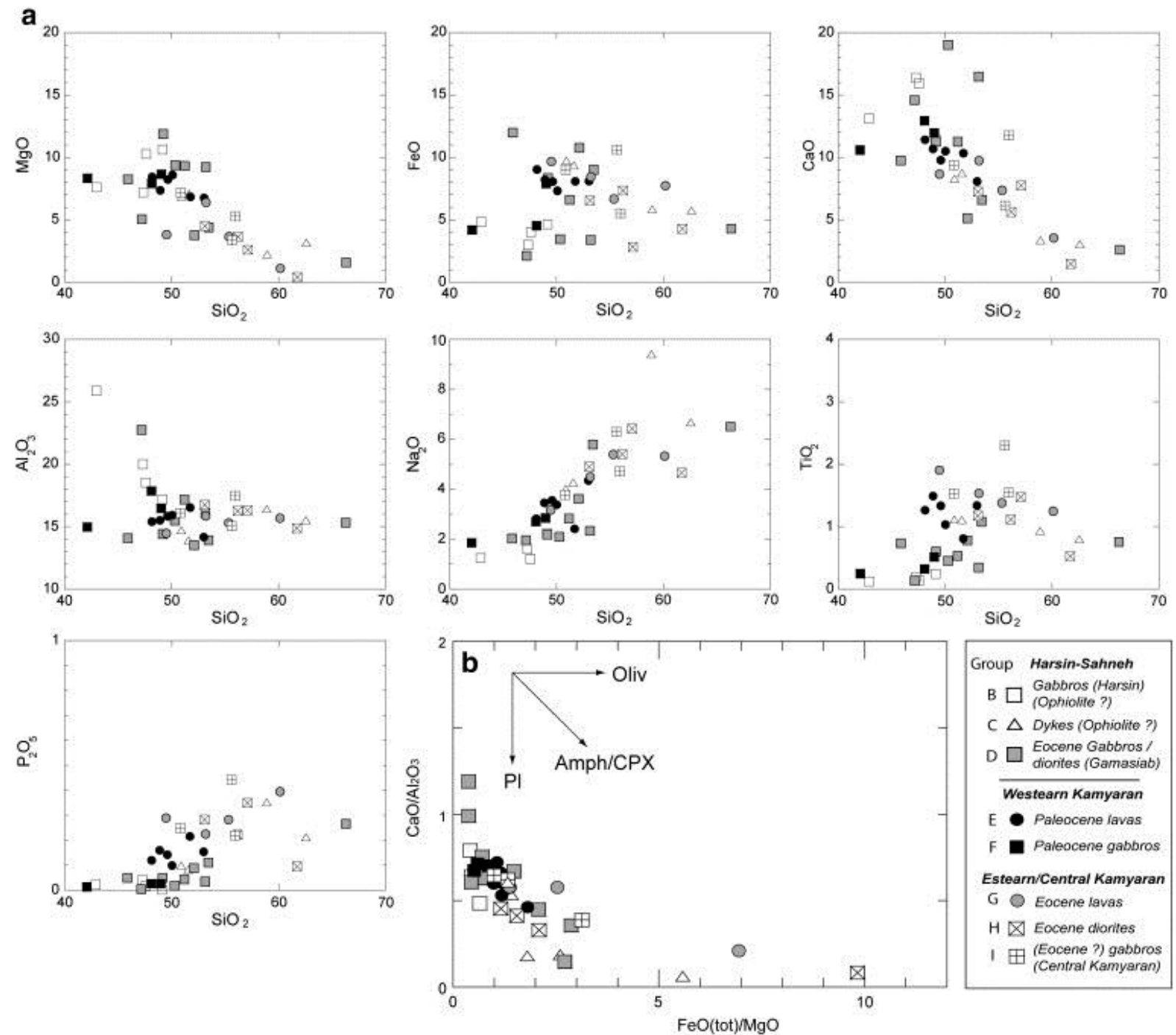

Fig. 6.

(a) $\mathrm{MgO}, \mathrm{FeO}, \mathrm{CaO}, \mathrm{Al}_{2} \mathrm{O}_{3}, \mathrm{Na}_{2} \mathrm{O}, \mathrm{TiO}_{2}$, and $\mathrm{P}_{2} \mathrm{O}_{5}$ versus $\mathrm{SiO}_{2}$ (wt.\%). (b) $\mathrm{CaO} / \mathrm{Al}_{2} \mathrm{O}_{3}$ versus $\mathrm{FeO} / \mathrm{MgO}$ diagram showing the trends induced by olivine, amphibole and/or plagioclase fractionation (alkaline Triassic to Liassic samples are not represented).

The generally negative trends of $\mathrm{MgO}$ and $\mathrm{CaO}$ for the most silica-rich samples $\left(\mathrm{SiO}_{2}>52\right.$ wt.\%) may result from the fractionation by clinopyroxene and/or amphibole, as shown by the $\mathrm{CaO} / \mathrm{Al}_{2} \mathrm{O}_{3}$ versus $\mathrm{FeO} / \mathrm{MgO}$ diagram ( Fig. 6b). For the samples with $\mathrm{SiO}_{2}<52$ wt. $\%$, the variation of these elements may be attributed to plagioclase fractionation.

\subsection{Trace elements}

In contrast to the major elements, the trace element composition of all of the samples is presented. The samples were classified according to their geochemical composition using trace elements considered to be completely insensitive to water-rock interaction, such as Th, Co, Ta (Hastie et al., 2007 and Pearce et al., 1981), and rare earth elements (REE). The results are given for each geological unit and, whenever possible, presented by age (Fig. 7a, b). The $\mathrm{Th} / \mathrm{Yb}$ versus $\mathrm{Ta} / \mathrm{Yb}$ diagram shows a range of mantle compositions from depleted MORB to enriched OIB; the calc-alkaline series from island arc tholeiite to shoshonite fall along the 
mantle array ( Fig. 7a). The Th versus Co diagram is included only for the calc-alkaline rocks in order to characterise the differentiation of the magma from basaltic to rhyolite in the various series, i.e., IAT, CA, and high-K shoshonite. The REE patterns and normalised multielement diagrams are shown and discussed below for the eight groups previously outlined and shown in Figs. 8a-h and $9 \mathrm{a}-\mathrm{h}$.
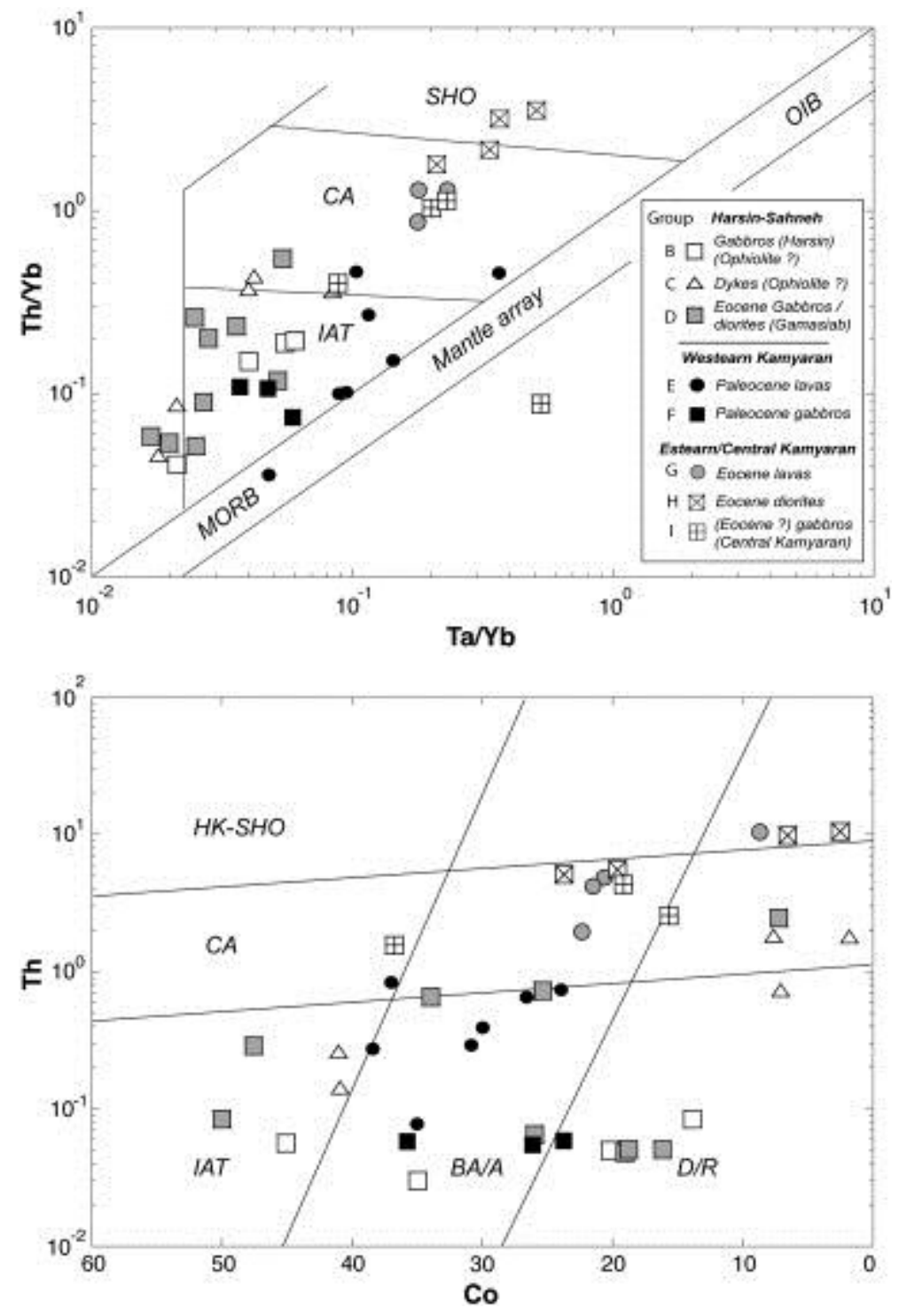

Fig. 7.

$\mathrm{Th} / \mathrm{Yb}$ versus $\mathrm{Ta} / \mathrm{Yb}$ ( Pearce et al., 1981), and Th versus $\mathrm{Co}$ ( Hastie et al., 2007) diagrams of the Harsin and Kamyaran samples. BA/A: basaltic andesite/andesite; D/R: dacite/rhyolite; CA: calc-alkaline; IAT: island arc tholeiite; M: MORB; SHO and HK-SHO: shoshonite and high-K shoshonite (alkaline Triassic to Liassic samples are not represented). 

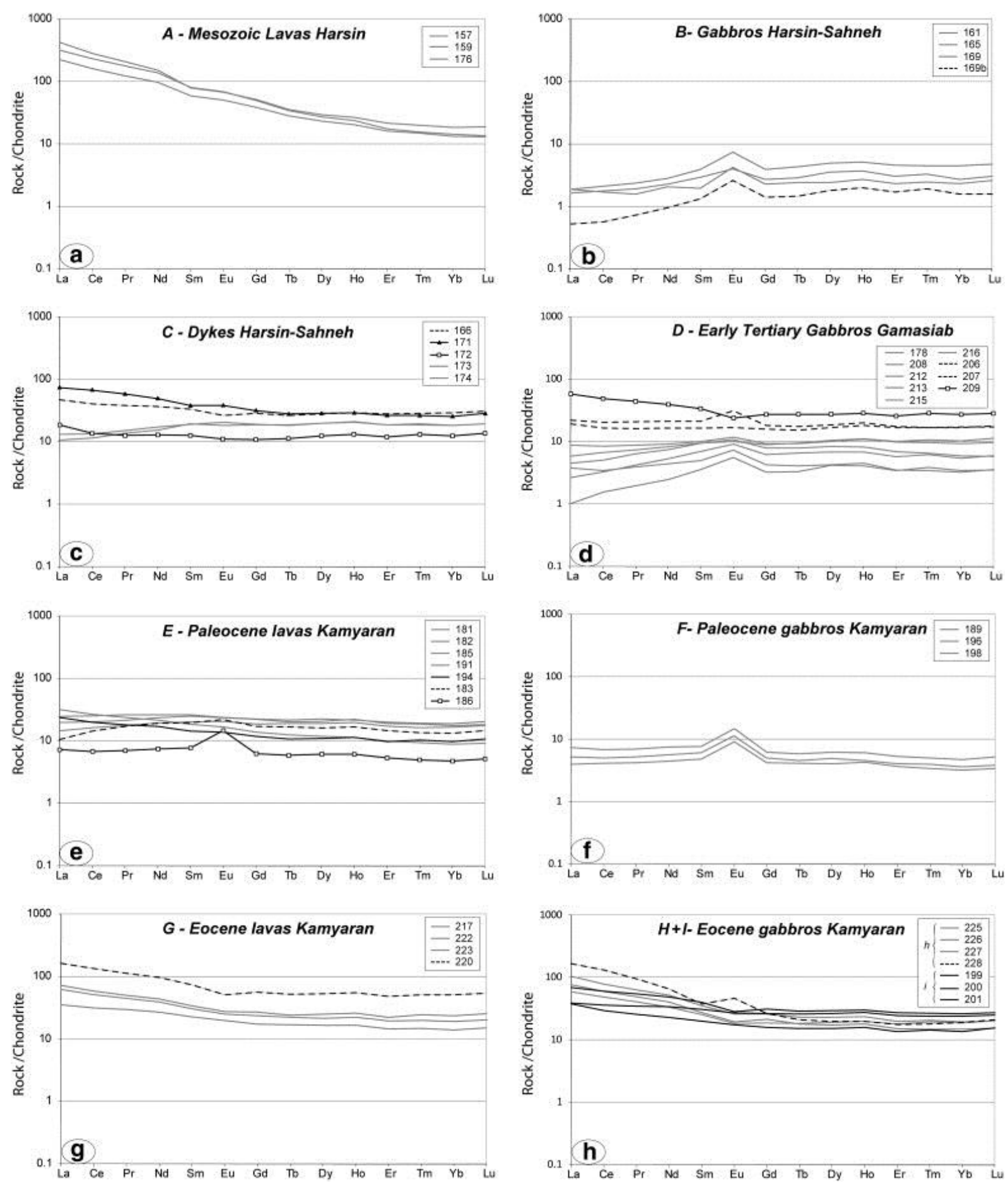

Fig. 8.

Rare earth element patterns normalised to chondritic values (Sun and McDonough, 1989); different symbols are given to the samples discussed in the text. 

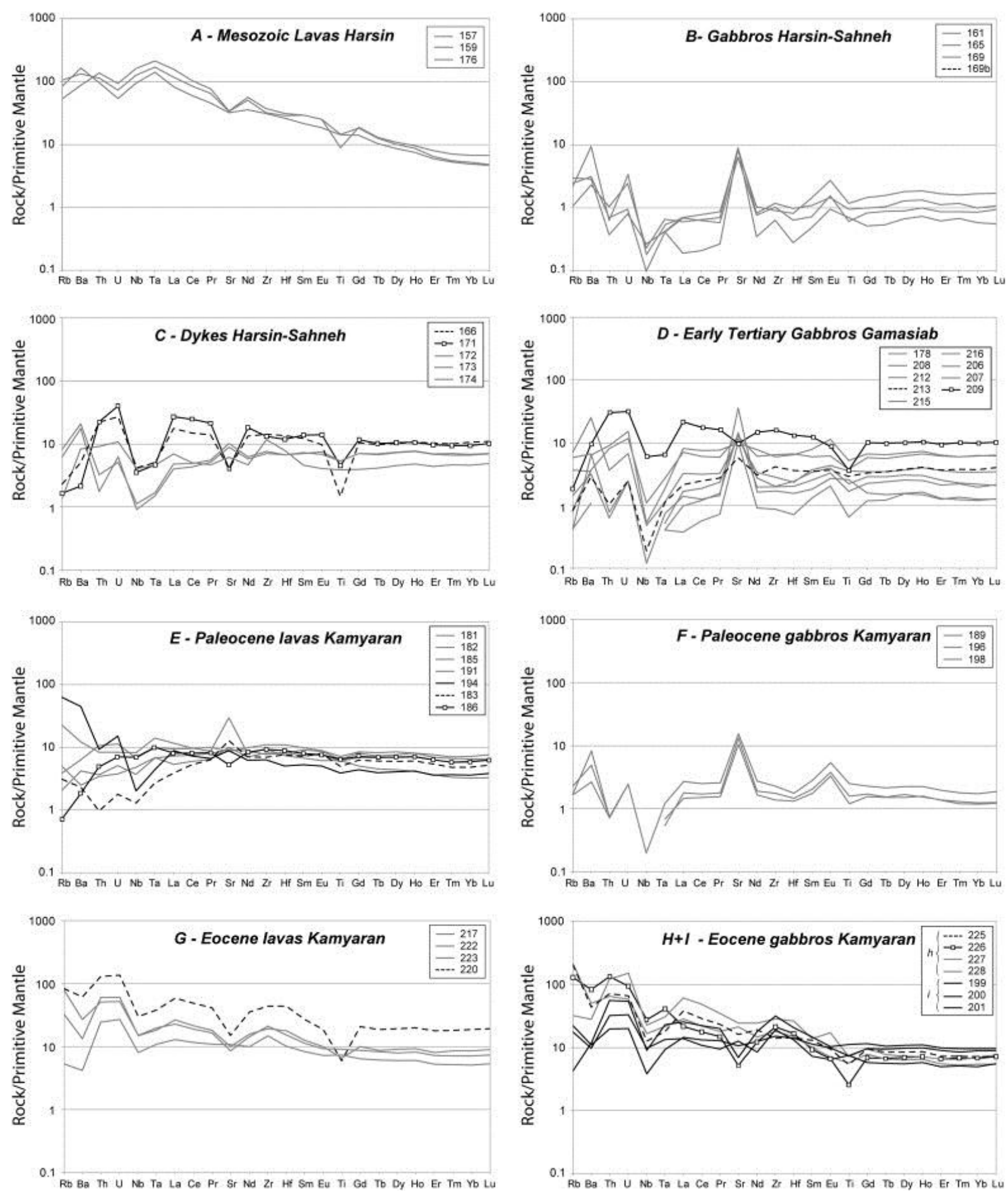

Fig. 9.

Multi-element diagrams normalised to the composition of the primitive mantle (Sun and McDonough, 1989); different symbols are given to samples discussed in the text.

\subsubsection{The Harsin-Sahneh region}

\subsubsection{Group A-Triassic to Liassic lavas}

In the $\mathrm{Th} / \mathrm{Yb}$ versus $\mathrm{Ta} / \mathrm{Yb}$ ratio plot ( Fig. $7 \mathrm{a})$, all samples $(157,159$, and 176$)$ are in the high-K field with OIB-like compositions. Their REE pattern ( Fig. 8a) is significantly light 
REE (LREE) enriched. The multi-element pattern ( Fig. 9a) reveals slightly negative anomalies in Ti, Sr, and $U$ for samples 157 and 159 and in $U$ only for sample 176 with a $\mathrm{Th} / \mathrm{U}=6$. These Triassic to Liassic samples clearly show REE and multi-element patterns characteristic of alkaline basalts of OIB affinity.

\subsubsection{Group B—presumed ophiolitic gabbros}

All of the gabbros fall in the island arc tholeiite (IAT) domain on Fig. 7a. In the Th versus Co diagram, the samples show a differentiation trend marked by decreasing Co content from gabbro to diorite ( Fig. 7b). The REE patterns ( Fig. 8b) reveal slightly positive Eu anomalies, suggesting plagioclase accumulation. LREE depletion with $[\mathrm{La} / \mathrm{Yb}]_{\mathrm{N}}$ between 0.39 (sample $169 \mathrm{~b}$ ) and 0.81 (sample 165) is characteristic of tholeiitic MORB-type magma. However, the multi-element patterns ( Fig. 9b) are very similar to each other with positive anomalies in $\mathrm{Sr}$, $\mathrm{Ba}$, and $\mathrm{Eu}$, which are likely linked to plagioclase accumulation. The negative anomalies in $\mathrm{Nb}$ and $\mathrm{Ta}$ and positive anomalies in $\mathrm{U}$ are considered to be a signature of a mantle source over a subduction zone. These trace element patterns resemble those from back-arc settings and suggest that these gabbros crystallised from magmas derived from a depleted mantle that was slightly metasomatised over a subduction zone (i.e., in an extensive area over the Mesozoic subduction zone). In any case, they cannot have been generated at a normal midoceanic ridge.

\subsubsection{Group $\mathrm{C}$ - presumed ophiolitic dykes}

All the dykes plot in the IAT field on Fig. 7a, two of them with particularly low $\mathrm{Ta} / \mathrm{Yb}$ ratios (very low Ta content). In the Th versus Co discrimination diagram ( Fig. 7b), two samples plot in the basaltic domain (i.e., samples 173 and 174) and three are more differentiated (i.e., samples 166, 172, and 171). The less differentiated samples (i.e., 173 and 174) display flat REE patterns in contrast to the most differentiated ones (i.e., samples 166, 171, and 172), which are significantly enriched in LREE, respectively ( Fig. 8a). The multi-element diagram shows that the most differentiated samples exhibit the largest negative anomalies in $\mathrm{Ti}, \mathrm{Sr}$, $\mathrm{Nb}, \mathrm{Ta}, \mathrm{Rb}$, and $\mathrm{Ba}$, whereas the less differentiated ones present positive anomalies in $\mathrm{Sr}, \mathrm{Rb}$, $\mathrm{Ba}$, and negative anomalies in $\mathrm{Nb}$ and $\mathrm{Ta}$. The negative anomalies in $\mathrm{Ti}, \mathrm{Nb}$, and $\mathrm{Ta}$ and the slightly positive anomalies in U-Th are the signature of calc-alkaline magmas. The low LOI of these samples exclude a hydrothermal alteration effect as an explanation of the enrichment or the depletion of the LILE elements between the differentiated samples and the less differentiated samples, particularly $\mathrm{Sr}, \mathrm{Rb}$, and $\mathrm{Ba}$. The dykes were most likely generated from mantle sources, metasomatised to different degrees by subduction derived fluids.

The multi-element profiles of samples 166, 171, and 172 are similar to the profile of gabbro 209, which is dated as Eocene. Considering the Cretaceous K-Ar ages given by Delaloye and Desmons (1980), the dykes could correspond to various magmatic events spanning the range from the Upper Cretaceous to the Eocene. The dykes with different degrees of differentiation exhibit trace element compositions that are very different from MORB. They were generated from metasomatised mantle, most likely by fluids derived from a subduction zone, which would account for the HFSE depletion.

\subsubsection{Group D—Tertiary gabbroic and dioritic intrusions (Ali-Abad, Gamasiab Valley)}

Samples 206, 207, 208, and 213 are located in the IAT domain of the $\mathrm{Th} / \mathrm{Yb}$ versus $\mathrm{Ta} / \mathrm{Yb}$ plot ( Fig. 7a), whereas sample 209 is calc-alkaline. The Th versus Co discrimination diagram 
shows an evolution from gabbros to granodioritic rocks for sample 209. The REE distribution diagram exhibits flat patterns for samples 206 and 207 ( Fig. 8d) to LREE depleted patterns for samples 208, 212, 213, 214, 215, 216, and 178. All of these samples exhibit moderate positive Eu anomalies linked to plagioclase accumulation. In contrast, the REE pattern of sample 209 is LREE enriched and shows a negative Eu anomaly.

The multi-element diagram (Fig. 9d) indicates negative anomalies in $\mathrm{Ti}, \mathrm{Nb}$, and $\mathrm{Ta}$ and positive $\mathrm{Sr}$ anomalies for all samples except sample 209 which has almost the same pattern as dykes 266, 271, and 272, which feed some of the gabbros. The multi-element pattern of sample 209 indicates a relative enrichment in $\mathrm{U}$ and $\mathrm{Th}$, a smaller depletion in $\mathrm{Nb}$ and $\mathrm{Ta}$, and negative $\mathrm{Sr}$ and $\mathrm{Ti}$ anomalies. Except for sample 213, all samples show moderate enrichment in $\mathrm{U}$ and $\mathrm{Th}$.

Although the REE patterns reveal LREE depletions to slight enrichments, the multi-element diagrams exhibit negative anomalies in $\mathrm{Nb}$, Ta, and $\mathrm{Ti}$ and, for most samples, positive anomalies in $\mathrm{Sr}$ and $\mathrm{U}$, which indicate a subduction-related origin. The different groups of these magmatic intrusions, cannot be cogenetic, since the gabbros and diorites are characterised by positive Eu anomaly, flat trends in chondrite normalised plots and granodioritic rocks characterised by negative Eu anomaly and negative $\mathrm{Nb}$ anomaly. Their geochemical compositions reflect different partial fusion rates and possibly different mantle sources overlying the subduction zone.

\subsubsection{The Kamyaran region}

\subsubsection{Group E-Paleocene lavas from western Kamyaran}

Most samples plot around the IAT field near the mantle array on Fig. 7a. When plotted in the Th versus Co classification diagram ( Fig. 7b), the samples are either basalts (i.e., samples 181 and 185) or basaltic andesites (i.e., samples 182, 183, and 186) belonging to the IAT domain or to the calc-alkaline field. REE diagrams reveal flat to slightly LREE enriched patterns, save for sample 183, which is LREE depleted ( Fig. 8e). There is no significant europium anomaly except sample 186, which most likely reflects a partial cumulative character.

The multi-element diagrams (Fig. 9e) show moderate depletions in $\mathrm{Ti}$ and $\mathrm{Nb}$ (save for a pronounced depletion for sample 194), variable $\mathrm{Sr}$ content, and a slight depletion in Th $\left([\mathrm{Th} / \mathrm{La}]_{\mathrm{PM}}=0.25\right.$ vs. 0.43 in average MORB). The incompatible LILE elements also show variable characteristics. The most silica rich samples 186 and 191 show two different patterns. Sample 191 has a negative $\mathrm{Nb}$ anomaly but positive $\mathrm{U}, \mathrm{Th}, \mathrm{Ba}$, and $\mathrm{Rb}$ anomalies. Sample 186 shows a slightly negative $\mathrm{Nb}$ anomaly and negative $\mathrm{U}, \mathrm{Th}, \mathrm{Ba}$, and $\mathrm{Rb}$ trend. The low LOI and weak Eu anomaly exclude a hydrothermal alteration effect or plagioclase fractionation or accumulation as an explanation for the character of the LILE. This suggests that the Paleocene lavas were generated from different metasomatised mantle sources.

To conclude, the Paleocene volcanic rocks exhibit a tholeiitic REE pattern, yet the multielement profiles suggest a subduction-related back-arc affinity, given the rather elevated $\mathrm{Nb} / \mathrm{Th}$ ratios (up to 11.5) and the geochemical characteristics similar to the volcanics of the Lau Basin (Boespflug et al., 1990, Hawkins, 1995 and Pearce et al., 1995), the Mariana Trough (Hawkins et al., 1990) and the Sumisu rift (Hochstaedter et al., 1990). 


\subsubsection{Group F-gabbros from western Kamyaran}

The gabbro samples 189, 196, and 198 have similar trace characteristics to the Paleocene lavas (Fig. 7a, b). The gabbro intrusions cut across the lavas discussed above which show similar flat REE profiles with a weak positive Eu anomaly (Fig. 8f). The multi-element diagrams, although incomplete (Fig. 9f), present a marked positive $\mathrm{Sr}$ anomaly and a negative anomaly in $\mathrm{Ta}$ (and $\mathrm{Nb}$, for sample 198). All of these intrusions exhibit tholeiitic REE profiles of cumulates. The multi-element diagrams suggest a calc-alkaline affinity, with negative Ta anomalies.

\subsubsection{Group G-Upper Eocene lavas from eastern Kamyaran}

Samples 217, 220, 222, and 223 plot in the calc-alkaline field on Fig. 7a, b. In Fig. 7b, sample 220 plots in the dacite/rhyolite field in contrast to the other samples. The REE patterns are very similar and are LREE enriched. Sample 220 appears to be highly differentiated and exhibits a slightly negative Eu anomaly (Fig. 8g).

The multi-element patterns (Fig. 9g) show an enrichment in $\mathrm{U}$ and Th and a slight depletion in $\mathrm{Nb}$ and $\mathrm{Ta}$. It has been noted that the negative anomaly is restricted to the differentiated samples 217 and 220. All these data again indicate a calc-alkaline affinity.

\subsubsection{Group $\mathrm{H}$ - gabbros from eastern Kamyaran}

On both Fig. 7a, b, samples shown in Figs. 8h, i and 9h, i (i.e., 225, 226, 227, and 228) straddle the boundary between the calc-alkaline and high-K shoshonite domains. Samples 226 and 228 plot in the granodiorite domain, whereas samples 225 and 227 are diorites ( Fig. 7b).

The samples have LREE enriched chondrite normalised patterns (Fig. 8h) with slightly negative $\mathrm{Eu}$ and $\mathrm{Nb}$ anomalies. The multi-element diagrams all show clear calc-alkaline characteristics, negative $\mathrm{Nb}$ and $\mathrm{Ta}$ and positive $\mathrm{U}$ and $\mathrm{Th}$ anomalies (Fig. 9h). In detail, however, they differ from each other. Sample 225 shows a conventional enrichment in $\mathrm{Th}-\mathrm{U}$, negative $\mathrm{Nb}$ and $\mathrm{Ti}$ anomalies. In contrast, sample 226 is characterised by a marked enrichment in $\mathrm{Th}$ and $\mathrm{U}$, a slight $\mathrm{Nb}$ anomaly and large negative anomalies in $\mathrm{Sr}$ and $\mathrm{Ti}$. The occurrence of small amounts of zircon may explain the significant enrichment in $\mathrm{Th}, \mathrm{U}$ and $\mathrm{Zr}$. These Upper Eocene age gabbros are considered to be typical calc-alkaline intrusions.

\subsubsection{Group I—gabbros and dioritic intrusions and associated dykes (central part of Kamyaran)}

These samples plot in the calc-alkaline domain (Fig. 7a), this is confirmed by the Th versus Co plot ( Fig. 7b), where samples 199 and 200 plot in the diorite field and, sample 201 in the gabbro field. REE and multi element patterns reveal characteristics of calc-alkaline rocks, i.e enrichment in LREE, Th, U and negative $\mathrm{Nb}$-Ta anomalies.

\section{Discussion}

\subsection{Nature of the Kermanshah ophiolite}

Wrobel-Daveau et al. (2010) suggest that the ophiolites of Harsin-Sahneh were part of a rifted basin at the ocean-continent transition zone, generated in the south of the Neo-Tethyan ocean. The existence of such a rifted basin has been proposed in some recent reconstructions of the 
Arabian platform on Iranian transects (Agard et al., 2011, Mouthereau et al., 2012 and Verges et al., 2011).

The three Triassic-Liassic OIB volcanic rocks, analysed in this study, are interpreted as evidence of plume interaction in the early rifting phase. These lavas most likely correspond to the magmatic basement of the radiolarites recognised by Braud (1987). Similar Triassic to Jurassic (Triassic in Neyriz; Ricou, 1974) rift-type alkaline basalts are observed in thrust units composed of radiolarites deposited in basins at the foot of the margin. These nappes occur systematically beneath the obducted ophiolites from Greece to Oman (Stampfli et al., 1991). This alkaline magmatism has been linked to the initial episode of lithospheric thinning (up to mantle denudation) under the influence of a mantle plume. This phase corresponds to the opening of the Neotethys in Triassic time (Ricou, 1994, Ricou et al., 1984, Stampfli et al., 1991 and Whitechurch et al., 1984).

Recently, Saccani et al. (2013) report occurrences of lava and dykes, covering or intruding peridotites, with OIB to E-MORB affinity. Accordingly, they interpret the entire HarsinSahneh ophiolite, irrespective of the age of the different units, as an accreted oceanic basin under the influence of a mantle plume situated at the ocean-continent transition zone of the southern margin of the Tethyan ocean.

However, apart from the three Triassic to Liassic volcanic samples that have a clear OIB signature, our analyses reveal that magmatic rocks of both the Harsin-Sahneh and Kamyaran domains have calc-alkaline signatures. They are not only present in the Paleocene-Eocene part of Kamyaran but also in the area earlier thought to represent ophiolitic remnants around Harsin-Sahneh and in the Eocene gabbros of the Gamasiab Valley. Contrary to the assertion of Allahyari et al. (2010), no typical MORB-type tholeiitic rock has been found among our samples. Even when REE patterns are depleted in LREE, their calc-alkaline affinity is marked by multi-element patterns typical of most subduction related magmatic rocks. Allahyari et al. (2010) themselves suggested that the enrichment in LREE observed in lherzolites and harzburgites are the result of the circulation of subduction-derived fluids in a depleted mantle after extraction of boninitic melts. Nevertheless, these geochemical signatures are in sharp contrast to those of the Tethyan MORB-like gabbros, dykes and volcanic rocks of the Oman ophiolite (Ernewein et al., 1988 and Pallister and Knight, 1981).

Two hypotheses for the origin of this presumed Harsin-Sahneh ophiolitic assemblage can be formulated. In the first, the gabbros and dykes that intrude the peridotites are not Mesozoic in age but are only related to the Paleocene-Eocene calc-alkaline magmatic events. These Tertiary magmatic rocks, intruded during a later stage a rifted Mesozoic oceanic basin lined with exhumed peridotites at the ocean-continent transition zone of the southern Tethyan margin. In the second hypothesis, all these basic-ultrabasic assemblages, at least north of Harsin, represent an intra-oceanic Upper-Cretaceous to Paleocene back-arc basin over the Tethyan subduction zone beneath Eurasia. Our geochemical data favour the second hypothesis.

\subsubsection{The Paleocene-Eocene subduction-related magmatism}

Sedimentary age constraints in the Kamyaran region and North of the Harsin-Sahneh, along the Gamasiab River, indicate that the subduction-related magmatism has been active mainly between the Paleocene and the Eocene (Braud, 1987), i.e., 65-60 to 50-45 Ma and perhaps lasted until the Late Eocene-Early Oligocene; additional radiometric ages at 34 and $26 \mathrm{Ma}$ 
have also been reported ( Delaloye and Desmons, 1980 and Leterrier, 1985; and this study). Given that the multi-element diagrams ( Fig. 9e, f, g, h) exhibit a moderate depletion in HFSE and LILE enrichment, the Paleocene magmatic group more likely corresponds to an immature back-arc rather than an arc setting.

There is a clear evolution of magmatic activity from the Upper Cretaceous (?)-Paleocene to the Eocene. The Paleocene lavas are basaltic to intermediate, with enriched to flat REE patterns. They show, apart from $\mathrm{Sr}$ anomalies, MORB-like depletion in the most incompatible elements for samples 186 and 183 or IAT like increase in these elements in sample 194. Most of the samples, except 186, exhibit negative $\mathrm{Nb}$, Ta anomalies. The Eocene lavas, such as the latite and rhyolite found North of Harsin along the Gamasyab River, are more differentiated and characterised by enriched LREE patterns, suggesting lower partial degrees of melting and/or stronger enrichment in incompatible elements of a metasomatised source.

Our data indicate that the Paleocene lavas and gabbros have intermediate MORB to $\operatorname{arc} \mathrm{Th} / \mathrm{Ta}$ ratios (Fig. 10a). In contrast, Eocene rocks have a clear arc signature. Here again, the geochemical data indicate that an Eocene magmatic arc superseded the Paleocene back-arc basin at the Eurasian continental margin. This interpretation is further supported by Fig. 10b, which shows that the samples have low $\mathrm{Th} / \mathrm{La}$ ratios indicating depleted mantle compositions similar to MORB. The Eocene rocks have higher Th/La ratios, indicating a mixing of MORBlike depleted mantle source with a sediment component characteristic of a mantle above subduction zones. 

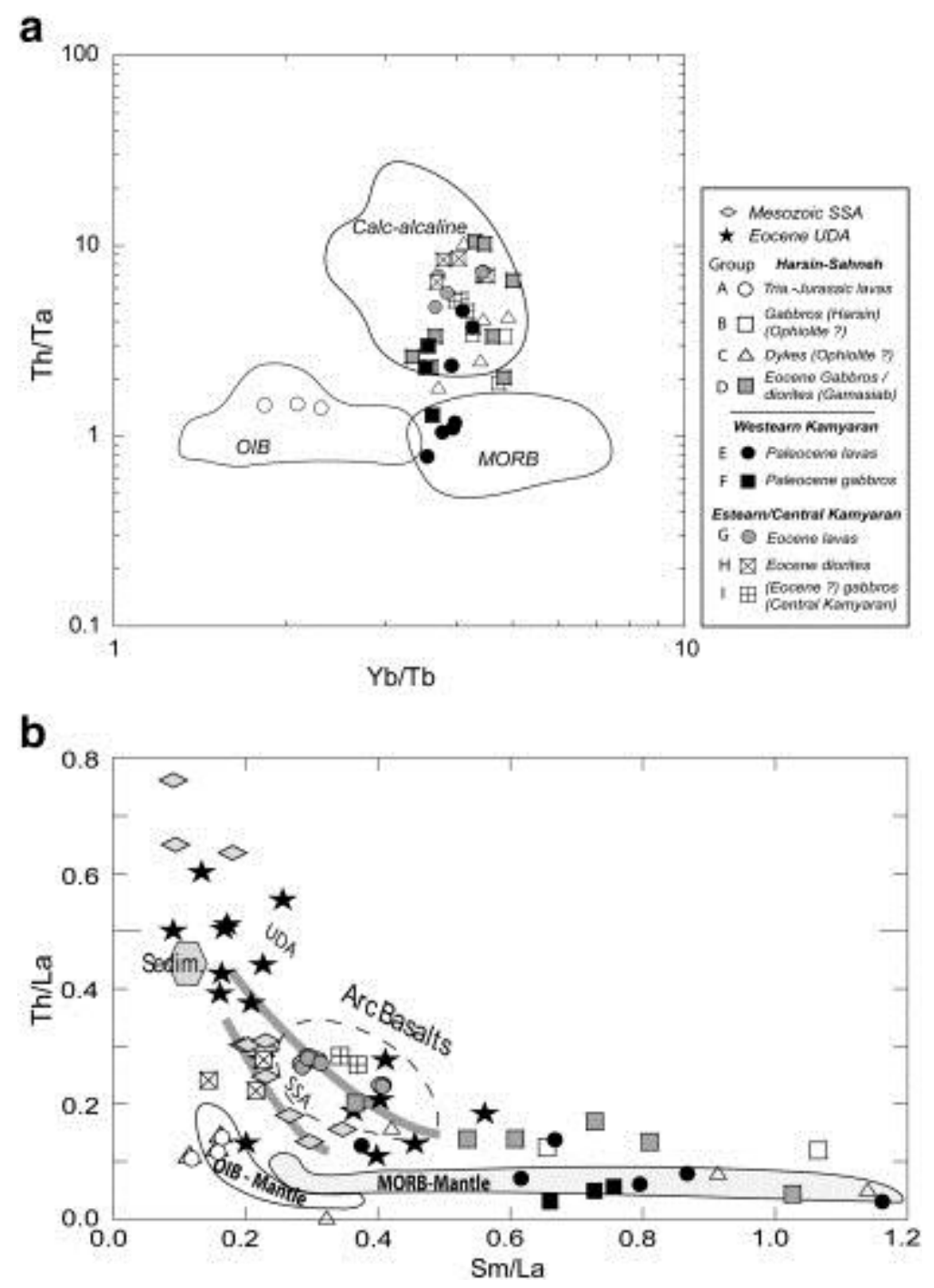

Fig. 10.

(a) $\mathrm{Th} / \mathrm{Ta}$ versus $\mathrm{Yb} / \mathrm{Tb}$ diagram ( Joron, 2000) showing the field of OIB, MORB and calcalkaline magma (CA); (b) Th/La versus Sm/La diagram ( Plank, 2005) showing the composition range of the OIB-MORB mantle sources and the oceanic sediments, the Urumieh-Dokhtar and Sanandaj-Sirjan Arc trends, the Kamyaran and Harsin Back-Arc Basin basalts and the Kamyaran Arc Basalts (see text for comments).

The fact that the Paleocene and Eocene volcanics are interlayered with proximal detrital turbidites, together with the lack of any suture zone between this domain and the Mesozoic Sanandaj-Sirjan arc, indicates that this Paleocene back-arc, crosscut by the Eocene arc must have been located close to the southern part of the Central Iranian block and has been attached to Eurasia since the Triassic.

The volcanic rocks were emplaced through a depleted harzburgitic basement, which occurs in tectonic slices interlayered with the volcanic rocks. Similarly, the Eocene gabbros from the Gamasiab Valley show the same geochemical characteristics as those from Kamyaran. The presence of peridotite slices in the calc-alkaline gabbros indicates that the Eocene gabbros are intrusive in mantle and not continental crust. The gabbros also cross cut Paleocene lavas and 
Eocene turbidites, indicating that they have emplaced through a domain evolving from a Paleocene back-arc to an Eocene arc environment at the northern edge of the Tethyan ocean.

\subsection{Geodynamic significance of the Early Tertiary arc}

The existence of an Upper Cretaceous (?) to Paleocene back-arc basin crosscut by an Eocene arc adjacent to the Eurasian upper plate and most likely resting on top of a mantle basement raises the question of its relationship to the calc-alkaline Sanandaj-Sirjan arc and the Urumieh-Dokhtar arc. These arcs were the loci of most of the magmatism along this northeast dipping subduction zone during Neotethyan convergence. The REE and multi-element patterns for Sanandaj-Sirjan and Urumieh-Dokhtar arcs on the overriding plate indicate that they have originated from similar, subduction-related mantle sources (Omrani et al., 2008). It is striking to note that the continental arc magmatism, which had ended in the Late Cretaceous in the Sanandaj-Sirjan arc, resumed from the Early-Middle Eocene onwards along the Urumieh-Dokhtar arc, but shifted inland some $300 \mathrm{~km}$ (Fig. 11) and following a quiescent period spanning roughly the same time as the Kermanshah Eocene arc (65-45 Ma). We note that the volume of Paleocene-Eocene magmatism is much smaller ( $<10$ times) than that of the Urumieh-Dokhtar arc. 

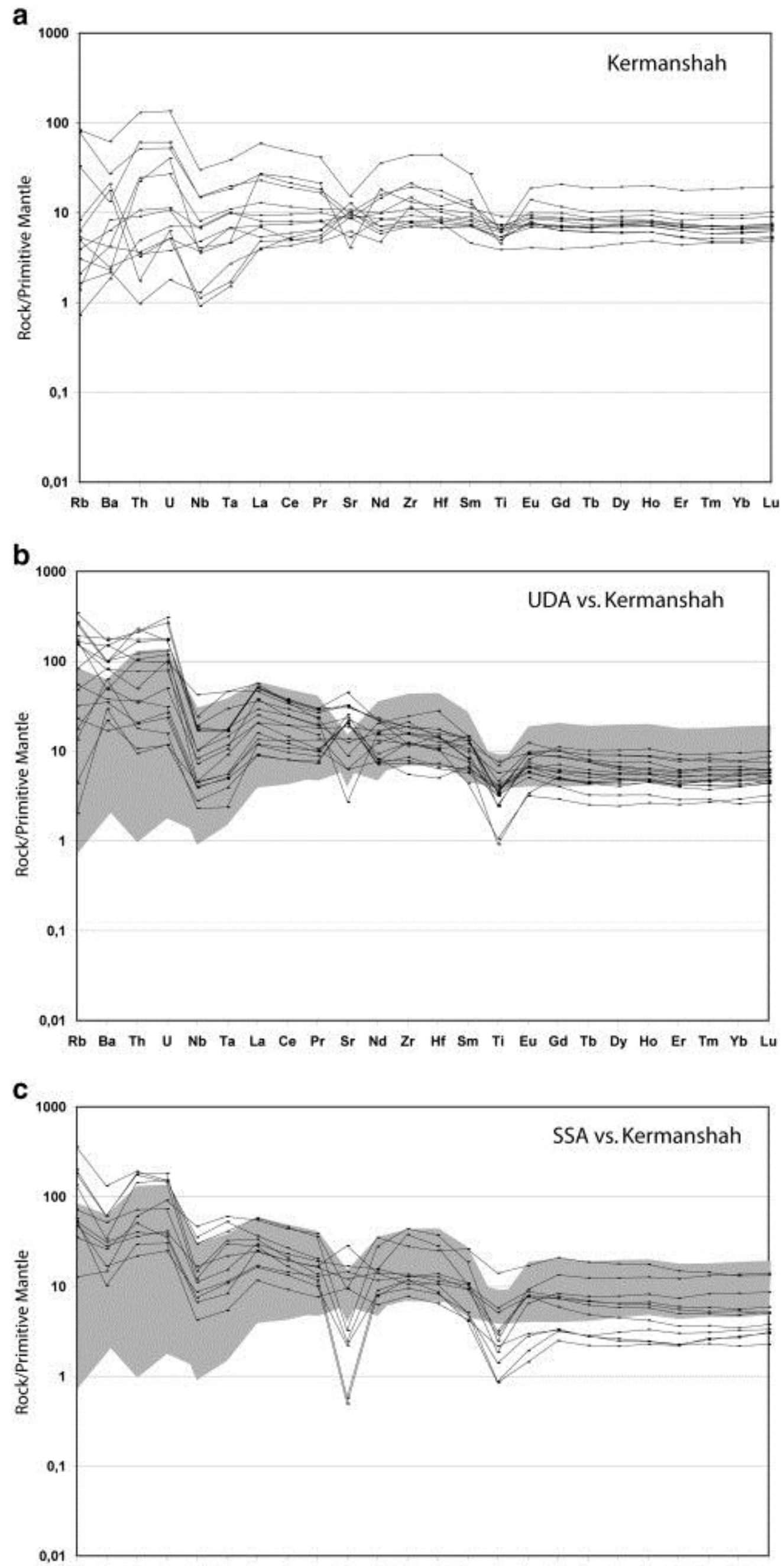

Rb Ba Th $U$ Nb Ta La Ce Pr Sr Nd Zr Hf Sm Ti Eu Gd Tb Dy Ho Er Tm Yb Lu 
Fig. 11.

Multi-element patterns of the Kermanshah lavas (in grey) compared to the TertiaryQuaternaryUmurieh-Doghtar Arc (UDA) and theMesozoic Sanandaj-Sirjan Arc (SSA) in the Sanandaj-Sirjan Zone (see text for comments).

A first-order comparison of the geochemistry of the Kermanshah, with the Sanandaj-Sirjan and the Urumieh-Dokhtar arcs (Fig. 12) shows that: (1) the Kermanshah samples are less differentiated, on average, than those of the Sanandaj-Sirjan arc and the Urumieh-Dokhtar arc, and their $\mathrm{K}_{2} \mathrm{O}$ content is generally lower (Omrani et al., 2008). The latter characteristic could stem from the fact that the Kermanshah arc is resting directly on top of the mantle and lacks continental crust; (2) multi-element diagrams for the Sanandaj-Sirjan and UrumiehDokhtar arcs are more enriched in incompatible elements than those of Kermanshah (Fig. 12), suggesting lower melting rates. The mantle source of the Paleocene-Eocene Kermanshah volcanics seems to be homogeneous with different degrees of partial melting, compared with the mantle sources of the Mesozoic Sanandaj-Sirjan arc and the Eocene Urumieh-Dokhtar arc, which seem to be rather heterogeneous (Fig. 10 and Omrani et al., 2008). Furthermore, the Paleocene-Eocene magmatism in Kermanshah was short-lived with respect to the duration of activity in the Sanandaj-Sirjan and Urumieh-Dokhtar arcs, yet it shows an evolution from back-arc basin to arc. We therefore propose that the late Eocene gabbros represent an evolution of the episode of back-arc spreading, leading to the mixing between depleted MORB-type and metasomatised arc-type mantle sources at the origin of the back-arc basin, before turning to a more typical arc-type magmatism (Kincaid and Hall, 2003).
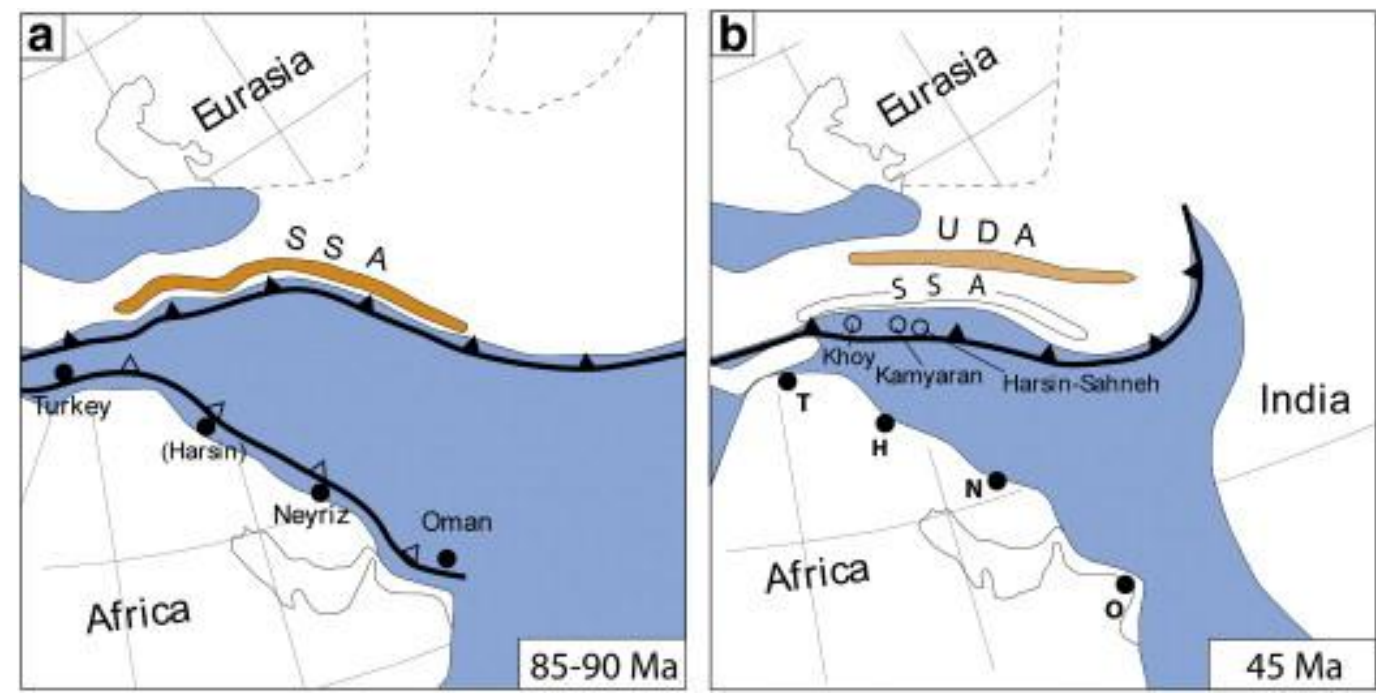

Fig. 12.

Two models showing the possible paleogeography and magmatic context of the Kermanshah exposures: (a) Upper Cretaceous situation (85-90 Ma) at the time of ophiolitic obduction onto the Arabian platform (Oman, and possibly a part of Neyriz and of Harsin). (b) Situation during the Middle Eocene (45 Ma), showing the existence of an intra-oceanic arc located at the foot of the Eurasian margin and responsible for the Kamyaran and Sahneh arc and back- 
arc basins whilst the Umurieh-Doghtar Arc (UDA) is starting to develop. The dark circles outline the composite character of the so-called Kermanshah "ophiolite".

A simple, hypothesis can be proposed to account for the magmatic evolution of the Eurasian margin (Fig. 13a). The magmatic activity in Kermanshah would have temporarily developed as the location of the magmatic front shifted in response to kinematic changes in the Tethyan convergence. During the Paleocene-Eocene the rate of convergence at the Eurasian continental margin slowed down following the dramatic kinematic change and ophiolite obduction that occurred in the Upper Cretaceous (e.g., Dewey et al., 1989 and Rosenbaum et al., 2002). This reduction in the rate of convergence may have caused the subducting slab to retreat, triggering the development of back-arc extension at the foot of the Eurasian margin. This would explain the mixed MORB and subduction-related geochemical signatures of the Paleocene Kermanshah magmatism ( Kincaid and Hall, 2003). 
Arabian plate

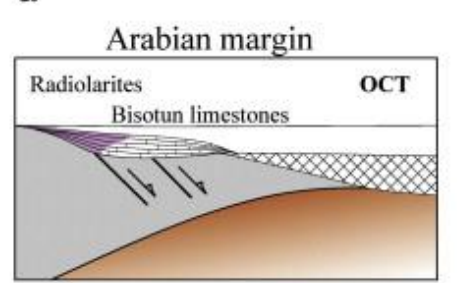

SSA

Eurasian plate
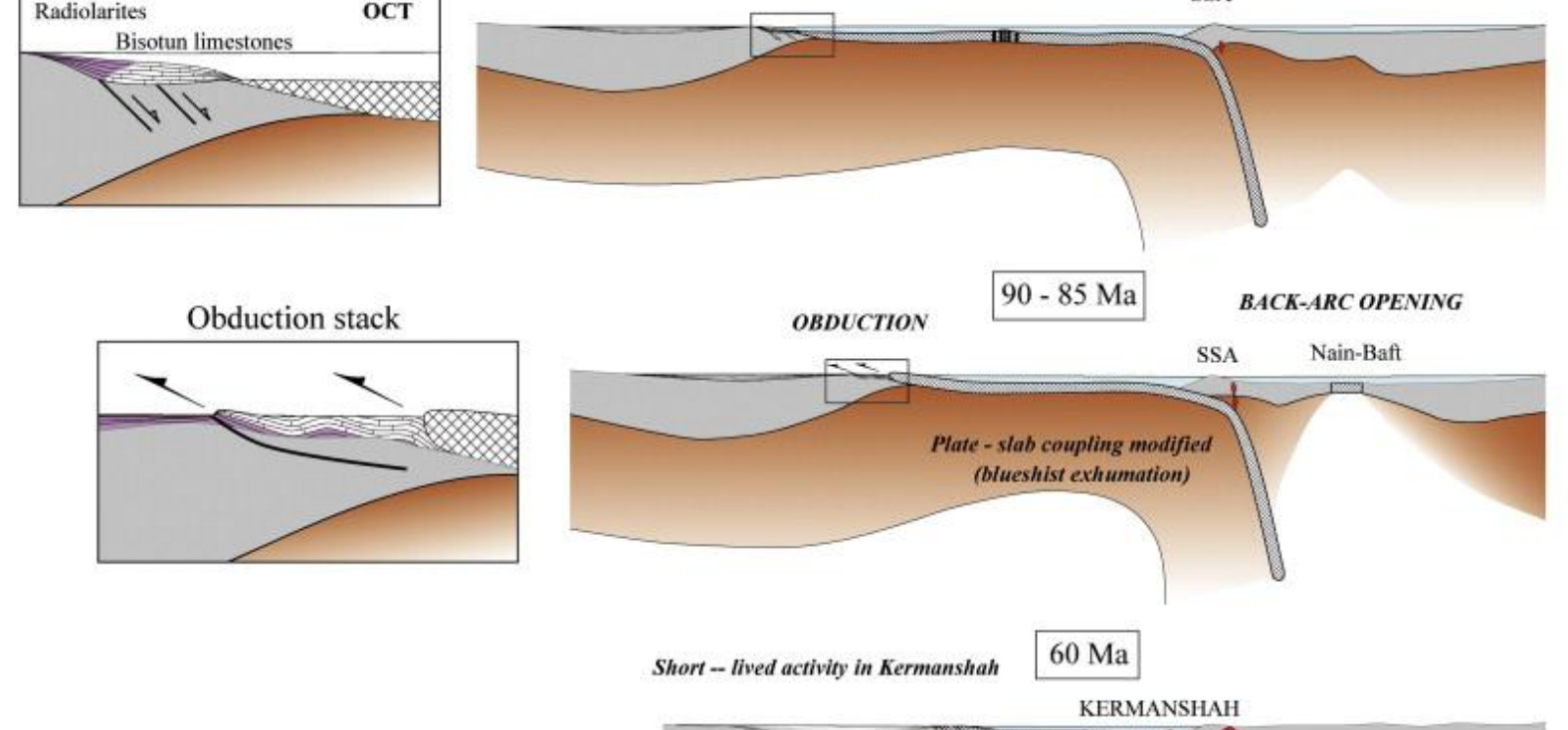

b Alternative hypothesis

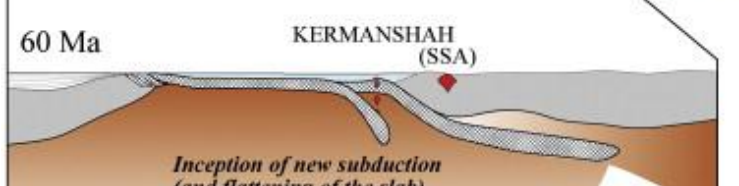
(and flattening of the slab)

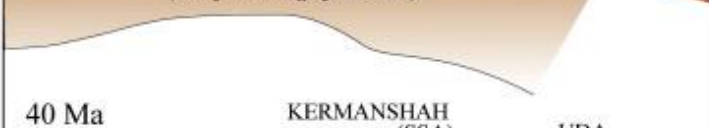

$40 \mathrm{Ma}$ (SSA)

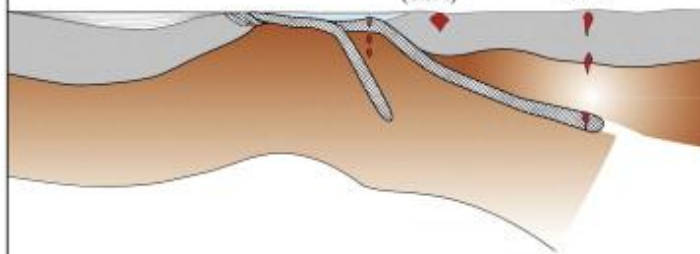

$10-5$ to $0 \mathrm{Ma}$
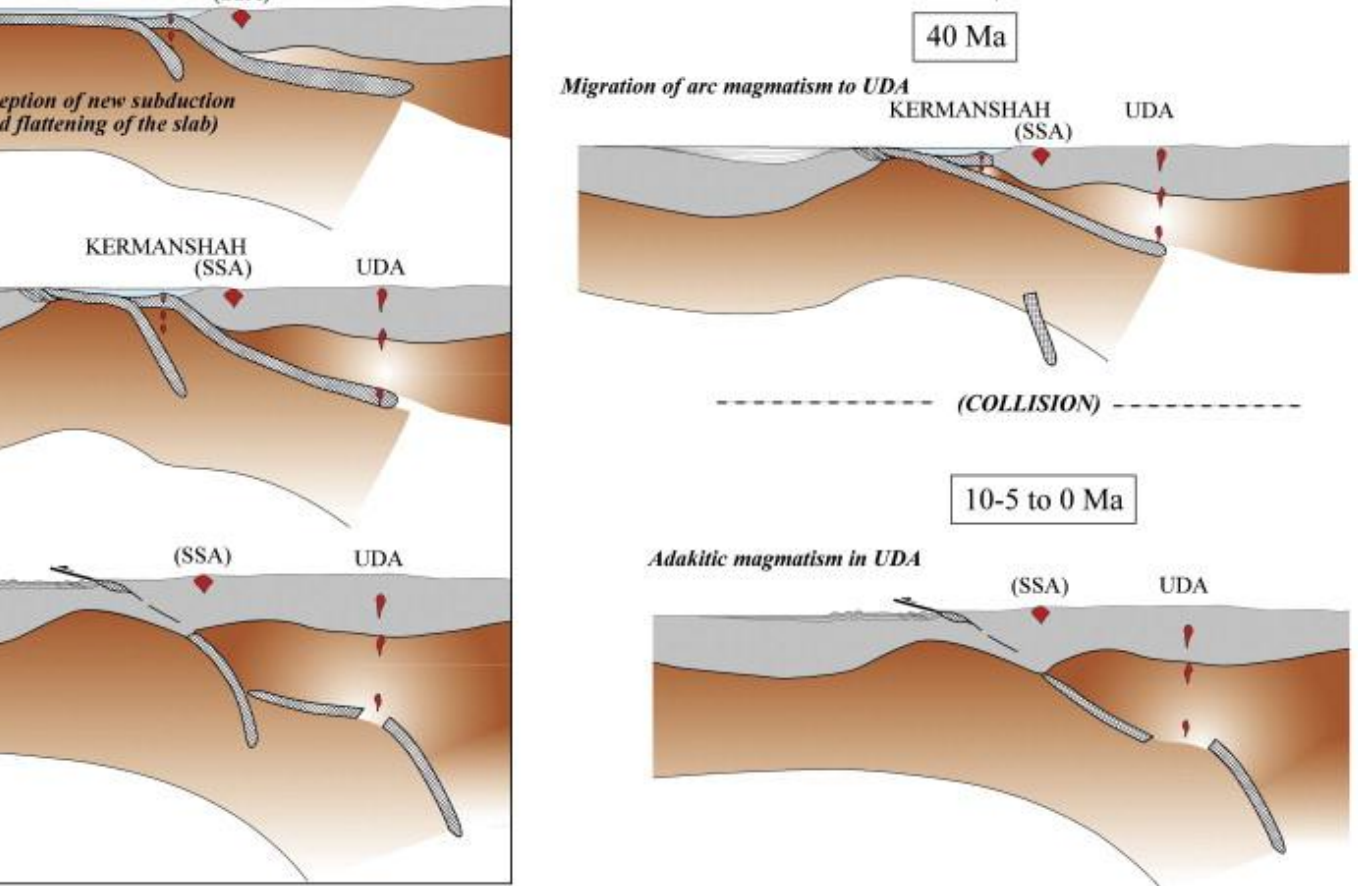

Adakitic magmatism in UDA

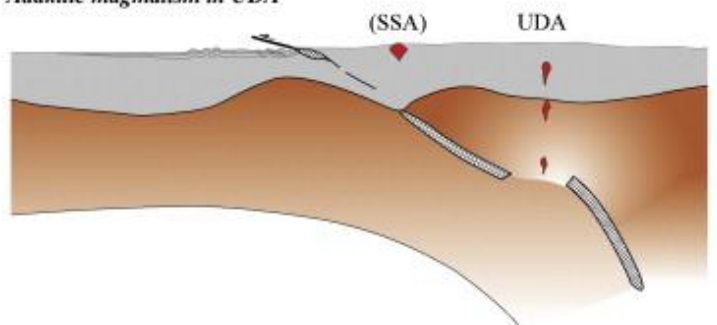

Fig. 13.

Simplified lithospheric-scale cross-sections showing the evolution through time of the obduction stack, the Upper Cretaceous situation and two distinct hypothesis (i.e., one or two slabs; see text for comments).

Slab break-off during the early Tertiary, as suggested by Hafkenscheid et al. (2006) and/or the beginning of the continental subduction as suggested by Bouilhol et al. (2013) for the India- 
Eurasia collision in Kohistan, would explain the flattening of the slab, the closure of the residual Tethyan basin and the northward shift from the Sanandaj-Sirjan arc to the UrumiehDokhtar arc after a quiescent period of continental arc magmatism (Omrani et al., 2008). The resumption of convergence at a $3 \mathrm{~cm} / \mathrm{yr}$ rate from ca. 55-50 Ma onwards (McQuarrie et al., 2003) would in turn account for the cessation of the magmatic activity near Kermanshah.

Our hypothesis is most feasible if the activity of the Kermanshah arc effectively occurred during the quiescent period between the magmatic activity of the Sanandaj-Sirjan arc and the Urumieh-Dokhtar arc (see also Agard et al., 2011). Further age constraints are necessary to strengthen our interpretation.

The alternative hypothesis would be that the magmatic activity in Kermanshah was related to a different, newly formed subduction zone. This hypothesis requires two slabs, however, and is less probable for the following reasons (Fig. 13b): (1) there is a space problem in creating a new subduction zone within an already small and vanishing oceanic basin, (2) the rupture of the oceanic lithosphere and the inception of a new subduction zone is known to be difficult from a mechanical point of view (e.g., Faccenna et al., 1999 and Stern, 2004), and 3) it would not explain the abrupt cessation of magmatic activity in Kermanshah.

\subsection{Peri-Arabic ophiolites and Paleocene-Eocene arcs from Turkey to Iran}

\subsubsection{Diversity of the Peri-Arabic ophiolites}

Although the obduction of most of the Peri-Arabic ophiolites from Turkey to Oman is considered to be synchronous during the Late Cretaceous (Coleman, 1971 and Ricou, 1971), their internal structure and origin are in fact not at all homogeneous. For instance, the Oman ophiolite is considered to be a portion of a fast spreading ridge in the Tethyan ocean (Nicolas and Boudier, 1995) or at an incipient subduction zone (Searle and Cox, 1999 and Shervais, 2001). In contrast, in the Neyriz ophiolite, the marble units rest on mantle peridotite and represent extensional allochtons detached from a continental margin. This ophiolite is therefore considered to have formed at the southern Tethyan continent-ocean transition zone (Jannessary, 2003). Further to the Northeast, the Khoy ophiolite (Fig. 1) belongs to two different domains. The northern one corresponds to a section of Jurassic oceanic crust underplated beneath the Sanandaj-Sirjan Zone. The southern one represents a Tertiary arc resting on Upper Cretaceous oceanic crust (Khalatbari-Jafari et al., 2003 and Khalatbari-Jafari et al., 2004Pessagno et al., 2005).

This paper presents evidence that the so-called Kermanshah ophiolite was an Eocene magmatic arc built on a Paleocene back-arc oceanic lithosphere at the distal part of the Eurasian margin. This composite assemblage of units are thus issued from the residual oceanic Tethyan realm that closed during the Oligocene (Agard et al., 2005). Furthermore, our work suggests that the Peri-Arabic obduction (Ricou, 1971) should be carefully reappraised. Evidences suggest that the thrusts that led to the final obduction initially affected domains with different paleogeographic features. In fact, the obducted material has diverse origins along the suture zone from Eastern Turkey to Oman, ranging from oceanic lithosphere with MORB affinity to arc or back-arc type units. Finally, little of Cretaceous oceanic lithosphere, involved in the main Upper Cretaceous obduction process around the Arabian Plate is preserved today in Iran and Eastern Turkey, most of it having been probably subducted. 


\subsubsection{Paleogeographic extension of the Paleocene back-arc-Eocene arc}

To the west and north, the so-called Kermanshah ophiolites extend into Iraq, where Upper Cretaceous subduction-related ophiolites and Eocene arc magmatism can also be traced into the Penjwen-Mawat-Rayat ophiolitic zone (Jassim and Buday, 2006). The upper part of the southern section of the Khoy ophiolite does indeed show some similarities to the Eocene group from Kermanshah: it has a calc-alkaline geochemical signature, and the volcanics are interlayered with Eocene sediments (Ghazi and Hassanipak, 1999 and Khalatbari-Jafari et al., 2004). Additionally, Vincent et al. (2005) reported a back-arc extension event in the south Caspian region (northern Iran) during the Middle Eocene, characterised by a thick sedimentary succession containing high-K alkali rift type basaltic lavas. This back-arc extension follows the northwards jump of the Lower Eocene arc described in this study to the Umurieh-Doktar magmatic arc, during middle-Eocene.

A similar domain was reported as a Cretaceous to Paleocene back-arc associated with an Eocene arc from southeastern Turkey (Aktas and Robertson, 1984, Robertson et al., 2007, Yigitbas and Yilmaz, 1996 and Yilmaz, 1993). For instance, the association of the Paleocene to Eocene Hazar-Maden complex on the Cretaceous Guleman ophiolites, south of the Bitlis and Pütürge Tauric blocks, resembles the geological relationship of the Khoy and Kermanshah "ophiolites" in Iran. In contrast, further to the west, in northwestern Syria (Parrot, 1977), Hatay, Cyprus and the Western Tauric ophiolites (Whitechurch et al., 1984), no such Paleocene back-arc or Eocene arc magmatic activity has been reported.

The existence of this Early Tertiary magmatic activity appears, therefore, to be restricted to the central part of the Peri-Arabic ophiolitic belt (Eastern Turkey-NW Zagros; Fig. 11). In line with this conclusion, we note that several paleogeographic contrasts exist along the strike of the Zagros orogen: the Amiran flysch is only found to the North of the Doruneh/Kazerun faults (Fig. 1), as is the Palaeocene-Eocene magmatic arc, whereas blueschist and Upper Cretaceous back-arc basin with typical MORB compositions (Agard et al., 2006, Arvin and Robinson, 1994 and Shafaii Moghadam et al., 2009) are only found to the south of this limit. A later, collision-related contrast in deformation style across the Kazerun fault is also evident (Bahroudi and Koyi, 2003 and Hessami et al., 2001).

\section{Conclusions}

1 .

The association of peridotites, gabbros, dykes and lavas described as an ophiolite by Braud (1987) has been related to the Upper Cretaceous Peri-Arabic obduction of NeoTethyan oceanic pieces (Ricou, 1971) onto the Arabian margin, however our study shows that the ophiolite has a polygenetic history. Furthermore, our analyses show that there is no remnant of a classical obducted ophiolite in the Kermanshah region, in the sense of a unique piece of oceanic lithosphere created at a spreading ridge, as in Oman or western Turkey.

The ophiolite represents either an Early Mesozoic rifted basin from the southern margin of the Tethys Ocean or an intra-oceanic Upper Cretaceous to Paleocene backarc basin, in either case crosscut by an Eocene arc. We favour the second hypothesis on geochemical grounds. 
3.

The Paleocene-Eocene magmatism in Kermanshah shows evidence of evolution from Paleocene tholeiitic back-arc type lavas to Eocene calc-alkaline arc magmatic rocks. This suggests that the Upper Cretaceous (?) to Paleocene intra-oceanic arc migrated first to the north during Eocene to settle, on the oceanic crust of the Paleocene back arc basin at the margin of Eurasia. This lower Eocene arc with its Paleocene oceanic substratum was then thrusted onto the Arabian margin during Late Eocene-Early Oligocene, at the beginning of the collision between Arabian and Eurasian margins.

4.

The Paleocene-Eocene magmatic activity developed during major kinematic changes of Tethyan convergence. This period corresponds to a major slowing down of the convergence rate of the northern Tethyan subduction zone, after the ophiolite obduction onto the Arabian platform (Agard et al., 2011). Such a change induced, during Upper Cretaceous (?)-Paleocene, slab retreat and back-arc extension, at the foot of the Eurasian margin. A first slab break-off in the Early Eocene could have resulted in the flattening of the slab and Eocene calc-alkaline magmatism. The latter magmatic episode occurred during the quiescent period as the magmatic activity shifted from the Sanandaj-Sirjan arc to the Urumieh-Dokhtar arc.

\section{Acknowledgements}

This study was funded by the MEBE programme (CNRS-University Pierre and Marie Curie of Paris-Consortium of oil companies). We are grateful to the Geological Survey of Iran and its General Manager for providing us full logistical support for fieldwork. We thank René Boutin of LHYGES (CNRS-Université de Strasbourg) for analyses of major and trace elements by ICP-MS and Michel Fialin (Camparis Center, UPMC, Univ Paris 06) for access to the microprobe. Professor S. Can Genç from the Istanbul Technical University (Turkey) and Andrew Kerr, Editor in chief of Lithos, are greatly acknowledged for their constructive comments that greatly helped to improve the quality of the article. We are indebted to Professor José Honnorez and Dr. Heather Sloan for having read the manuscript and improved the English.

\section{References}

Agard et al., 2005

P. Agard, J. Omrani, L. Jolivet, F. Mouthereau

Convergence history across Zagros (Iran): constraints from collisional and earlier deformation

International Journal of Earth Sciences (Geologische Rundschau), 94 (2005), pp. $401-419$

Agard et al., 2006

P. Agard, P. Monie, W. Gerber, J. Omrani, M. Molinaro, B. Meyer, L. Labrousse, B.

Vrielynck, L. Jolivet, P. Yamato 
Transient, synobduction exhumation of Zagros blueschists inferred from $\mathrm{P}-\mathrm{T}$, deformation, time and kinematic constraints: implications for Neotethyan wedge dynamics

Journal of Geophysical Research, 111 (2006)

Agard et al., 2007

P. Agard, L. Jolivet, B. Vrielynck, E. Burov, P. Monie

Plate acceleration: the obduction trigger?

Earth and Planetary Science Letters, 258 (2007), pp. 428-441

Agard et al., 2011

P. Agard, J. Omrani, L. Jolivet, H. Whitechurch, B. Vrielynck, W. Spakman, P. Monie, B. Meyer, R. Wortel

Zagros orogeny: a subduction-dominated process

Geological Magazine, 148 (2011), pp. 692-725

http://dx.doi.org/10.1017/S001675681100046X

Aktas and Robertson, 1984

G. Aktas, A.H.F. Robertson

The Maden Complex, SE Turkey: evolution of a Neotethyan continental margin ,in: J.E. Dixon, A.H.F. Robertson (Eds.), The Geological Evolution of the Eastern Mediterranean, Geol. Soc. Spec. Publ., 17, Blackwell Sci. Publ., Oxford (1984), pp. 375-402

Alavi, 1994

M. Alavi

Tectonic of the Zagros orogenic belt of Iran: new data and interpretations

Tectonophysics, 229 (1994), pp. 211-238

Allahyari et al., 2010

K. Allahyari, E. Saccani, M. Pourmoafi, L. Beccaluva, F. Masoudi

Petrology of mantle peridotites and intrusive mafic rocks from the Kermanshah ophiolitic complex (Zagros belt, Iran): implications for the geodynamic evolution of the Neo-Tethyan oceanic branch between Arabia and Iran

Ofioliti, 35 (2010), pp. 71-90

Arvin and Robinson, 1994

M. Arvin, P.T. Robinson

The petrogenesis and tectonic setting of lavas from the Baft ophiolitic melange, southwest of Kerman, Iran

Canadian Journal of Earth Sciences, 31 (1994), pp. 824-834

Bahroudi and Koyi, 2003

A. Bahroudi, H. Koyi

Effect of spatial distribution of Hormuz salt on deformation style in the Zagros

fold and thrust belt: an analogue modelling approach

Journal of the Geological Society, 160 (2003), pp. 719-733

Ballato et al., 2011

P. Ballato, C.E. Uba, A. Landgraf, M.R. Strecker, M. Sudo, D.F. Stockli, A. Friedrich,

S.H. Tabatabaei 
Arabia-Eurasia continental collision: insights from late Tertiary foreland-basin evolution in the Alborz Mountains, northern Iran

Geological Society of America Bulletin, 123 (1-2) (2011), pp. 106-131

Berberian, 1995

M. Berberian

Master "blind" thrust faults hidden under the Zagros folds: active basement tectonics and surface morphotectonics

Tectonophysics, 241 (1995), pp. 193-195

Berberian and Berberian, 1981

F. Berberian, M. Berberian

Tectono-Plutonic episodes in Iran

H.K. Gupta, F.M. Delany (Eds.), Zagroz-Hindu Kush-Himalaya Geodynamic Evolution, American Geophysical Union \& Geological Society of America, Washington (1981), pp. 5-32

Boespflug et al., 1990

X. Boespflug, L. Dosso, H. Bougault, W.J. Pegram, J.L. Joron

Arc and Back-arc geochemical features of the Lau Basin: trace element and isotopic $(\mathrm{Sr}, \mathrm{Nd}, \mathrm{Pb})$ data

Eos, Transactions of the American Geophysical Union, 71 (1990), p. 1019

Bouihol et al., 2013

P. Bouihol, O. Jagoutz, J.M. Hanchar, F.O. Dudas

Dating India-Eurasia collision through arc-magmatism records

Earth and Planetray Science Letters, 366 (2013), pp. 163-175

Braud, 1987

J. Braud

La suture du Zagros au niveau de Kermanshah (Kurdistan iranien): reconstitution paléogéographique, évolution géodynamique, magmatique et structurale

Université Paris-Sud (1987), p. 450

Braud and Bellon, 1974

J. Braud, H. Bellon

Données nouvelles sur le domaine métamorphique du Zagros (zone de SanandajSirjan) au niveau de Kermanshah-Hamadan (Iran): nature âge et interprétation des séries métamorphiques et des intrusions; évolution structurale

Rapport Université Paris-Sud (1974) (20 pp.)

Coleman, 1971

R.G. Coleman

Plate tectonic emplacement of upper mantle peridotites along continental edges

Journal of Geophysical Research, 76 (1971), pp. 1212-1222

Coleman, 1981

R.G. Coleman

Tectonic setting for ophiolite obduction in Oman

Journal of Geophysical Research, 86 (1981), pp. 2497-2508

Cox et al., 1979 
K.G. Cox, J.D. Bell, R.J. Pankhurst

The Interpretation of Igneous Rocks

George Allen and Unwin, London (1979) (450 pp.)

Delaloye and Desmons, 1980

M. Delaloye, J. Desmons

Ophiolites and melange terranes in Iran: a geochronological study and its

paleotectonic implications

Tectonophysics, 68 (1980), pp. 83-111

Dercourt et al., 1986

J. Dercourt, L.P. Zonenshain, L.E. Ricou, V.G. Kazmin, X. Le Pichon, A.L. Knipper, C. Grandjacquet, I.M. Sbortshikov, J. Geyssant, C. Lepvrier, D.H. Pechersky, J. Boulin, J.-C. Sibuet, L.A. Savostin, O. Sorokhtin, M. Westphal, M.L. Bazhenov, J.P. Lauer, B. BijuDuval

Geological evolution of the Tethys belt from the Atlantic to the Pamirs since the LIAS

Tectonophysics, 123 (1986), pp. 241-315

Desmons and Beccaluva, 1983

J. Desmons, L. Beccaluva

Mid-ocean ridge and island-arc affinities in ophiolites from Iran: palaeographic implications: complementary reference

Chemical Geology, 39 (1983), pp. 39-63

Dewey et al., 1989

J.F. Dewey, M.L. Helman, E. Turco, D.H.W. Hutton, S.D. Knott

Kinematics of the western Mediterranean

M.P. Coward, D. Dietrich, R.G. Park (Eds.), Alpine Chain, Geological Society of London, special Publication, London (1989), pp. 265-283

Dick and Bullen, 1984

H.J.B. Dick, T. Bullen

Chromian spinel as a petrogenetic indicator in abyssal and alpine-type peridotites and spatially associated lavas

Contribution to Mineralogy and Petrology, 86 (1984), pp. 54-76

Ernewein et al., 1988

M. Ernewein, C. Pflumio, H. Whitechurch

The death of an accretion zone as evidenced by the magmatic history of the Sumail ophiolite (Oman)

Tectonophysics, 151 (1988), pp. 247-274

Faccenna et al., 1999

C. Faccenna, D. Giardini, P. Davy, A. Argentieri

Initiation of subduction at Atlantic-type margins: insights from laboratory

experiments

Journal of Geophysical Research, 104 (1999), pp. 2749-2766

Falcon, 1974

N.L. Falcon

Southern Iran: Zagros Mountains 
A.M. Spencer (Ed.), Mesozoic-Cenozoic Orogenic Belts, Geological Society, Special Publications, London (1974), pp. 199-211

Gharib and De Wever, 2010

F. Gharib, P. De Wever

Radiolaires mésozoïques de la formation de Kermanshah (Iran)

Comptes Rendus Palevol, 9 (2010), pp. 209-219

Ghazi and Hassanipak, 1999

A.M. Ghazi, A.A. Hassanipak

Geochemistry of subalkaline and alkaline extrusives from the Kermanshah

ophiolite, Zagros Suture Zone, Western Iran: implications for Tethyan plate tectonics

Journal of Asian Earth Sciences, 17 (1999), pp. 319-332

Guillot et al., 2003

S. Guillot, G. Garzanti, D. Baratoux, D. Marquer, G. Maheo, J. de Sigoyer

Reconstructing the total shortening history of the NW Himalaya

Geochemistry, Geophysics, Geosystems, 4 (7) (2003), p. 1064

http://dx.doi.org/10.1029/2002GC000484.2003

Hacker, 1994

B.R. Hacker

Rapid emplacement of young oceanic lithosphere: argon geochronology of the Oman ophiolite

Science, 265 (1994), pp. 1563-1565

Hafkenscheid et al., 2006

E. Hafkenscheid, M.J.R. Wortel, W. Spakman

Subduction history of the Tethyan derived seismic tomography and tectonic reconstruction

Journal of Geophysical Research, 111 (2006), p. B08401

http://dx.doi.org/10.1029/2005JB003791

Hall, 1981

R. Hall

L'interprétation des skarns au contact entre les marbres et les péridotites du massif ophiolitique de Neyriz (Zagros sud-oriental, Iran)

Comptes Rendus de l'Académie des Sciences, 293 (1981), pp. 315-320

Hastie et al., 2007

A.R. Hastie, A.C. Kerr, J.A. Pearce, S.F. Mitchell

Classification of altered volcanic island arc rocks using immobile trace elements: development of the Th-Co discrimination diagram

Journal of Petrology, 48 (2007), pp. 2341-2357

Hatzfeld et al., 2003

D. Hatzfeld, M. Tatar, K. Priestley, M. Ghafory-Ashtiany

Seismological constraints on the crustal structure beneath the Zagros Mountain belt (Iran)

Geophysical Journal International, 155 (2003), pp. 403-410 
Hawkins, 1995

J.W. Hawkins

The geology of the Lau Basin

B. Taylor (Ed.), Backarc Basins: Tectonics and Magmatism, Plenum, New York (1995), pp. 63-138

Hawkins et al., 1990

J.W. Hawkins, P.F. Lonsdale, J.D. Macdougall, A.M. Volpe

Petrology of the axial ridge of the Mariana Trough back-arc spreading center

Earth and Planetary Science Letters, 100 (1990), pp. 226-250

Hebert and Laurent, 1990

R. Hebert, R. Laurent

Mineral chemistry of the plutonic section of the Troodos Ophiolite: new constraints for genesis of arc-related ophiolites, in Ophiolites Oceanic Crustal Analogues

Proceedings of the Symposium Troodos 1987, 1990, Geol. Survey Dep., Nicosia, Cyprus (1990), pp. 149-163

Hessami et al., 2001

K. Hessami, H.A. Koyi, C.J. Tabolt

The significance of strike-slip faulting in the basement of the Zagros fold and thrust belt

Journal of Petroleum Geology, 24 (2001), pp. 5-28

Hochstaedter et al., 1990

A.G. Hochstaedter, J.B. Gill, M. Kusakabe, S. Newman, M. Pringle, B. Taylor, P. Fryer Volcanism in the Sumisu Rift, I. Major element, volatile, and stable isotope geochemistry

Earth and Planetary Science Letters, 100 (B08401) (1990)

http://dx.doi.org/10.1029/2005JB003791

Homke et al., 2004

S. Homke, J. Verges, M. Garces, H. Emami, R. Karpuz

Magnetostratigraphy of Miocene-Pliocene Zagros foreland deposits in the front of the Push-e Kush Arc (Lurestan Province, Iran)

Earth and Planetary Science Letters, 225 (2004), pp. 397-410

Homke et al., 2009

S.P. Homke, J. Vergés, J. Serra-Kiel, G. Bernaola, I. Sharp, M. Garcés, I. Montero-Verdù, R. Karpuz, M.H. Goodarzi

Late Cretaceous-Paleocene formation of the proto-Zagros foreland basin, Lurestan Province, SW Iran

Geological Society of America Bulletin, 121 (2009), pp. 963-978

Huot et al., 2002

F. Huot, R. Hebert, V. Varfalvy, G. Beaudoin, C. Wang, Z. Liu, J. Cotten, J. Dostal

The Beimarang melange (southern Tibet) brings additional constraints in assessing the origin, metamorphic evolution and obduction processes of the Yarlung Zangbo ophiolite

Journal of Asian Earth Sciences, 21 (2002), pp. 307-322 
Ichii et al., 1992

T. Ichii, P.T. Robinson, H. Mekawa, R. Fiske

Petrological studies of peridotites from diapiric serpentinite seamounts in the IzuOgasawara Mariana fore-arc, Leg 125

In Fryer P., Pearce J.A., Stockking L.B., et al, 1992. Proceedings of the Ocean Drilling Program, Scientific Results, 125 (1992), pp. 445-485

Jahangiri, 2007

A. Jahangiri

Post-collisional Miocene adakitic volcanism in NW Iran: geochemical and geodynamic implications

Journal of Asian Earth Sciences, 30 (2007), pp. 433-447

Jannessary, 2003

M.R. Jannessary

Les ophiolites de Neyriz (Sud de l'Iran): naissance d'une dorsale en pied de marge continentale (étude des structures internes, de la fabrique du manteau, et de l'évolution pétro-géochimique des magmas)

Phd Thesis L'Université Louis Pasteur de Strasbourg, Strasbourg (2003), p. 221

Jassim and Buday, 2006

S.Z. Jassim, T. Buday

Units of unstable shelf and the Zagros suture

S.Z. Jassim, J.C. Goff (Eds.), Geology of Iraq, Dolin, Prague and Moravian Museum (2006), pp. 71-83

Joron, 2000

J.L. Joron

Thèse de doctorat d'Etat

Université Paris VII (2000) (967 pages)

Karimi Bavandpour, 1999

A. Karimi Bavandpour

Geological Map of Kermanshah

Geological Survey of Iran (1999)

Khalatbari-Jafari et al., 2003

M. Khalatbari-Jafari, T. Juteau, H. Bellon, H. Emami

Discovery of two ophiolite complexes of different ages in the Khoy area (NW Iran)

Comptes Rendus Geosciences, 335 (2003), pp. 917-929

Khalatbari-Jafari et al., 2004

M. Khalatbari-Jafari, T. Juteau, H. Bellon, H. Whitechurch, J. Cotton, H. Emami

New geological and geochronological investigations on Khoy ophiolites and related formations

NW Iran. Journal of Asian Earth Sciences, 23 (2004), pp. 507-535

Kincaid and Hall, 2003

C. Kincaid, P.S. Hall

Role of back arc spreading in circulation and melting at subduction zones 
Journal of Geophysical Research, 108 (2003)

Lacombe et al., 2007

O. Lacombe, K. Amrouch, F. Mouthereau, L. Dissez

Calcite twinning constraints on late Neogene stress patterns and deformation mechanisms in the active Zagros collision belt

Geology, 35 (2007), pp. 263-266

Lanphere and Pamic, 1983

M.A. Lanphere, J. Pamic

40Ar/39Ar ages and tectonic setting of ophiolite from the Neyriz area, southeast

Zagros Range, Iran

Tectonophysics, 96 (1983), pp. 245-256

Leterrier, 1985

J. Leterrier

Mineralogical, geochemical and isotopic evolution of two Miocene mafic

intrusions from the Zagros (Iran)

Lithos, 18 (1985), pp. 311-329

McDonough and Sun, 1995

W.F. McDonough, S.-s. Sun

The composition of the Earth

Chemical Evolution of the Mantle, 120 (1995), pp. 223-253

McQuarrie et al., 2003

N. McQuarrie, J.M. Stock, C. Verdel, B.P. Wernicke

Cenozoic evolution of Neotethys and implications for the causes of plate motions

Geophysical Research Letters, 30 (2003) http://dx.doi.org/10.1029/2003GL017992

Molinaro et al., 2005

M. Molinaro, P. Leturmy, J.C. Guezou, D. Frizon de Lamotte, S.A. Eshraghi

The structure and kinematics of the southeastern Zagros fold-thrust belt, Iran: from thin-skinned to thick-skinned tectonics

Tectonics, 24 (2005) http://dx.doi.org/10.1029/2004TC001633

Monié and Agard, 2009

P. Monié, P. Agard

Coeval blueschist exhumation along thousands of kilometers: implications for subduction channel processes

Geochemistry, Geophysics, Geosystems, 10 (7) (2009)

http://dx.doi.org/10.1029/2009GC002428

Mouthereau et al., 2007

F. Mouthereau, J. Tensi, N. Bellahsen, O. Lacombe, T. De Boisgrollier, S. Kargar

Tertiary sequence of deformation in a thin-skinned/thick-skinned collision belt: the Zagros Folded Belt (Fars, Iran)

Tectonics, 26 (2007), p. 5 http://dx.doi.org/10.1029/2007TC002098

Mouthereau et al., 2012

F. Mouthereau, O. Lacombe, J. Vergés 
Building the Zagros collisional orogen: timing, strain distribution and the dynamics of Arabia/Eurasia plate convergence

Tectonophysics, 532-535 (2012), pp. 27-60

Nicolas, 1989

A. Nicolas

Structures in Ophiolites and Dynamics of Oceanic Lithosphere

Kluwer, Dordrecht (1989)

Nicolas and Boudier, 1995

A. Nicolas, F. Boudier

Mapping oceanic ridge segments in Oman ophiolites

Journal of Geophysical Research, 100 (B4) (1995), pp. 6179-6197

Nicolas et al., 1980

A. Nicolas, F. Boudier, J.L. Bouchez

Interpretation of peridotite structures from ophiolitic and oceanic environments

American Journ. of Sciences, E.D. Jackson Mem., volume, 280 A (1980), pp.

$192-210$

Omrani et al., 2008

J. Omrani, P. Agard, H. Whitechurch, M. Benoit, G. Prouteau, L. Jolivet

Arc-magmatism and subduction history beneath Zagros: new report of adakites and geodynamic consequences

Lithos, 106 (3-4) (2008), pp. 380-398

Pallister and Knight, 1981

J.S. Pallister, R.J. Knight

Rare-earth element geochemistry of the Samail Ophiolite near Ibra, Oman

Journal of Geophysical Research, 86 (1981), pp. 2673-2697

Parrot, 1977

J.F. Parrot

Ophiolites du nord-ouest syrien et evolution de la croute oceanique tethysienne au cours du mesozoique

Tectonophysics, 41 (1977), pp. 251-268

Pearce and Norry, 1979

J.A. Pearce, M.J. Norry

Petrogenetic implications od $\mathrm{Ti}, \mathrm{Zr}, \mathrm{Y}$ and $\mathrm{Nb}$ variations in volcanic rocks

Contribution to Mineralogy and Petrology, 69 (1979), pp. 33-47

Pearce et al., 1981

J.A. Pearce, T. Alabaster, A.W. Shelton

The Oman ophiolite as a Cretaceous arc-basin complex: evidence and implications Philosophical Transactions of the Royal Society of London. Series A,

Mathematical and Physical Sciences, 300 (1981), pp. 299-300

Pearce et al., 1995

J.A. Pearce, P. Baker, P.K. Harvey, I.W. Luff

Geochemical evidence for subduction fluxes, mantle melting and fractional crystallization beneath the South Sandwich Island arc 
36 (1995), pp. 1073-1109

Pessagno et al., 2005

E.A. Pessagno, A.M. Ghazi, M. Kariminia, R.A. Duncan, A.A. Hassanipak

Tectonostratigraphy of the Khoy Complex, northwestern Iran

Stratigraphy, 2 (2005), pp. 49-63

Plank, 2005

T. Plank

Constraints from thorium/lanthanum on sediment recycling at subduction zones and the evolution of the continents

Journal of Petrology, 46 (2005), pp. 921-944

Ricou, 1971

L.E. Ricou

Le croissant ophiolitique péri-arabe, une ceinture de nappes mise en place au crétacé supérieur

Revue de Géographie Physique et de Géologie Dynamique, 18 (1971), pp. 327350

Ricou, 1974

L.E. Ricou

L'étude géologique de la région de Neyriz (Zagros iranien) et l'évolution

structurale des Zagrides

Thèse Orsay (1974) (321 pp.)

Ricou, 1976

L.E. Ricou

Evolution structurale des Zagrides

La région clef de Neyriz (Zagros Iranien), Mémoires de la Société géologique de France, 125 (1976) (140 pp.)

Ricou, 1994

L.E. Ricou

Tethys reconstructed: plates continental fragments and their boundaries since $260 \mathrm{Ma}$ from Central America to South-eastern Asia

Geodinamica Acta, 7 (1994), pp. 169-218

Ricou et al., 1977

L.-E. Ricou, J. Braud, J.H. Brunn

Le Zagros

Livre à la mémoire de A.F. de Lapparent (1905-1975), Mémoire hors Série de la Société Géologique de France, 8 (1977), pp. 33-52

Ricou et al., 1984

L.E. Ricou, J. Marcoux, H. Whitechurch

The Mesozoic organisation of the Taurides: one or several ocean basins?

,in: J.E. Dixon, A.H.F. Robertson (Eds.), The Geological Evolution of the Eastern Mediterranean, Geol. Soc. Spec. Publ., 17, Blackwell Sci. Publ., Oxford (1984), pp. 349-359 
Robertson et al., 2007

A.H.F. Robertson, O. Parlak, T. Rízaoğlu, Ü. Ünlügenç, N. İnan, K. Tasli, T. Ustaömer Tectonic evolution of the South Tethyan ocean: evidence from the Eastern Taurus Mountains (Elaziğ region, SE Turkey)

Geological Society, London, Special Publications, 272 (2007), pp. 231-270

Rosenbaum et al., 2002

G. Rosenbaum, G.S. Lister, C. Duboz

Relative motions of Africa, Iberia and Europe during Alpine orogeny

Tectonophysics, 359 (2002), pp. 117-129

Saccani et al., 2013

E. Saccani, K. Allahyari, L. Beccaluva, G. Bianchini

Geochemistry and petrology of the Kermanshah ophiolites (Iran): implication for the interaction between passive rifting, oceanic accretion, and OIB-type

components in the Southern Neo-Tethys Ocean

Gondwana Research, 24 (1) (2013), pp. 392-411

Saidi et al., 1997

A. Saidi, M.F. Brunet, L.E. Ricou

Continental accretion of the Iran Block to Eurasia as seen from late Paleozoic to early Cretaceous subsidence curves

Geodinamica Acta, 10 (1997), pp. 189-208

Searle and Cox, 1999

M. Searle, J. Cox

Tectonic setting, origin, and obduction of the Oman ophiolite

Geological Society of America Bulletin, 111 (1999), pp. 104-122

Sengor, 1990

A.M.C. Sengor

A new model for the late Palaeozoic-Mesozoic tectonic evolution of Iran and implications for Oman

Geological Society, London, Special Publications, 49 (1990), pp. 797-831

Sengor et al., 1988

A.M.C. Sengor, D. Altiner, A. Cin, T. Ustomer, K.J. Hsu

The origin and assembly of the Tethyside orogenic collage at the expense of Gondwana land

,in: M.G. Audley-Charles, A. Hallam (Eds.), Gondwana and Tethys, Geological Society Special Publication, Geological Society (1988), pp. 119-181

Shafaii Moghadam et al., 2009

H. Shafaii Moghadam, M. Rahgoshay, A. Banitaba

Geochemistry and petrogenesis of basaltic flows in the Nain-Dehshir ophiolites Iranian Society of Crystallography and Mineralogy, 16 (2009), pp. 603-612

Shahidi and Nazari, 1997

A. Shahidi, H. Nazari

Geological Map of Harsin

Geological Survey of Iran (1997)

Shervais, 2001 
J.W. Shervais

Birth, death, and resurrection: the life cycle of suprasubduction zone ophiolites

Geochemistry, Geophysics, Geosystems, 2 (2001)

http://dx.doi.org/10.1029/2000GC000080

Stampfli and Borel, 2002

G.M. Stampfli, G.D. Borel

A plate tectonic model for the Paleozoic and Mesozoic constrained by dynamic plate boundaries and restored synthetic oceanic isochrons

Earth and Planetary Science Letters, 196 (2002), pp. 17-33

Stampfli et al., 1991

G. Stampfli, J. Marcoux, A. Baud

Tethyan margins in space and time

Palaeogeography, Palaeoclimatology, Palaeoecology, 87 (1991), pp. 373-409

Stern, 2004

R.J. Stern

Subduction initiation: spontaneous and induced

Earth and Planetary Science Letters, 226 (2004), pp. 275-292

Stöcklin, 1968

J. Stöcklin

Structural history and tectonics of Iran: a review

American Association of Petroleum Geologists Bulletin, 52 (1968), pp. 1229-1258

Sun and McDonough, 1989

S. Sun, W.F. McDonough

Chemical and isotopic systematics of oceanic basalts: implications for mantle composition and processes

A.D. Saunders, M.J. Norry (Eds.), Magmatism in the Ocean Basins, Geological Society, London (1989), pp. 313-345

Tchalenko and Braud, 1974

J.S. Tchalenko, J. Braud

Seismicity and structure of the Zagros (Iran): the Main Recent Fault between 33 and $35^{\circ} \mathrm{N}$

Philosophical Transactions of the Royal Society of London, 277 (1974), pp. 1-25

Thuizat et al., 1981

R. Thuizat, H. Whitechurch, R. Montigny, T. Juteau

$\mathrm{K}$-Ar dating of some infra-ophiolitic metamorphic soles from the Eastern

Mediterranean: new evidence for oceanic thrustings before obduction

Earth and Planetary Science Letters, 52 (1981), pp. 302-310

Tilton et al., 1981

G.R. Tilton, C.A. Hopson, W. Wright

Uranium-lead isotopic ages of the Samail ophiolite, Oman, with applications to

Tethyan ocean ridge tectonics

Journal of Geophysical Research, 86 (B4) (1981), pp. 2763-2775

Van Huen and Allen, 2011

J. Van Huen, M. Allen 
Continental collision and slab break-off: a comparison of 3-D numerical models with observations

Earth and Planetary Science Letters, 302 (2011), pp. 27-37

Verges et al., 2011

J. Verges, E. Saura, E. Casciello, M. Fernandez, A. Vellasenor, I. Jimenez-Munt, D. Garcia-Castellanos

Crustal-scale cross-sections across the NW Zagros belt: implications for the Arabian margin reconstruction

Geological Magazine, 148 (2011), pp. 739-761

Vincent et al., 2005

S.J. Vincent, M.B. Allen, A.D. Ismail-Zadeh, R. Flecker, K.A. Foland, M.D. Simmons Insights from the Talysh of Azerbaijan into the Paleogene evolution of the South Caspian region

Geological Society of America Bulletin, 117 (2005), pp. 1513-1533

Whitechurch et al., 1984

H. Whitechurch, T. Juteau, R. Montigny

Role of the Eastern Mediterranean ophiolites (Turkey, Syria, Cyprus) in the history of the Neo-Tethys

,in: J.E. Dixon, A.H.F. Robertson (Eds.), The Geological Evolution of the Eastern Mediterranean, Geol. Soc. Spec. Publ., 17, Blackwell Sci. Publ., Oxford (1984), pp. 301-317

Wrobel-Daveau et al., 2010

J.C. Wrobel-Daveau, J.C. Ringenbach, S. Tavakoli, G. Ruiz, P. Masse, D.

FrizondeLamotte

Evidence for mantle exhumation along the Arabian margin in the Zagros

(Kermanshah area, Iran)

Arabian Journal of GeosciencesSpringer Berlin/Heidelberg (2010), pp. 499-513

Yigitbas and Yilmaz, 1996

C. Yigitbas, Y. Yilmaz

Post-Late Cretaceous strike-slip tectonics and its implications for the Southeast

Anatolian Orogen, Turkey

International Geology Review, 38 (1996), pp. 818-831

Yilmaz, 1993

Y. Yilmaz

New evidence and model of evolution of the southeast Anatolian orogen

Geological Society of America Bulletin, 105 (1993), pp. 251-271 